\title{
PLAYING BY PORNOGRAPHY'S RULES: THE REGULATION OF SEXUAL EXPRESSION
}

\author{
DAVID Cole†
}

\section{INTRODUCTION}

Sometimes a sentence is worth a thousand words. In 1964, as the Supreme Court stumbled toward a constitutional approach to obscenity, Justice Potter Stewart suggested that only "hard-core pornography" should be suppressed. ${ }^{1}$ He admitted that the category may be incapable of "intelligibl[e]" definition, but nonetheless confidently asserted, "I know it when I see it."2

Justice Stewart's sentence captures the essence of the Court's sexual expression jurisprudence, which rests more on the assertion of distinctions than on reasoned analysis. For many years, the Court, unable to agree upon a doctrinal framework for obscenity regulation, simply ruled by per curiam judgments, without offering any explanation for what it was doing. ${ }^{3}$ When the Court did attempt to explain its actions, some suggested that it would have been better off maintaining its silence. ${ }^{4}$

The Court has now put forward a set of doctrinal "rules" that in the end do little more than obscure what is basically Stewart's intuitive approach. In defining obscenity, the Court has advanced an incoherent formula that requires the application of "community

† Professor of Law, Georgetown University Law Center. I would like to thank Craig Bloom, Adam Breznick, Anne Dailey, Jonathan Elmer, Bill Eskridge, Cindy Estlund, Marjorie Heins, Ellen Hertz, Sam Issacharoff, Jules Lobel, Carlin Meyer, David Myers, Dan Ortiz, Gary Peller, Nina Pillard, Larry Rosen, Mike Seidman, Nomi Stolzenberg, Nadine Strossen, Mark Tushnet, Suzanne Underwald, and Franz Werro for their helpful comments and suggestions on various drafts.

I was or am counsel for plaintiffs in Finley v. National Endowment for the Arts, 795 F. Supp. 1457 (C.D. Cal. 1992); Gay Men's Health Crisis v. Sullivan, 792 F. Supp. 278 (S.D.N.Y. 1992); and Wojnarowicz v. American Family Ass'n, 745 F. Supp. 130 (S.D.N.Y. 1990); and counsel for defendants in United States v. Eichman, 496 U.S. 310 (1990); and Texas v. Johnson, 491 U.S. 397 (1989), discussed herein.

1 Jacobellis v. Ohio, 378 U.S. 184, 197 (1964) (Stewart, J., concurring).

2 Id.

${ }^{3}$ See, e.g., Redrup v. New York, 386 U.S. 767, 770-71 (1967) (per curiam); see also Paris Adult Theatre I v. Slaton, 413 U.S. 49, 83 (1973) (Brennan, J., dissenting) (criticizing per curiam approach to resolving obscenity cases).

ISee, e.g., Harry Kalven, Jr., The Metaphysics of the Law of Obscenity, 1960 SuP. CT. REv. 1, 44 (quoting Thurman Arnold's defense of the Court's per curiam approach as one that "neatly" avoids the "futile and desperate game" of defining hard-core pornography). 
standards" without any specification of what constitutes a "community"; the identification of national "reasonable" judgments about artistic and literary taste, a subject on which reason may be of little guidance and on which the nation is likely to have no consensus; ${ }^{6}$ the differentiation of healthy from "shameful or morbid" sexual interests; ${ }^{7}$ and the determination that speech is "patently offensive, ${ }^{88}$ a judgment which in nonsexual circumstances is a reason for protecting, not criminalizing speech. ${ }^{9}$

Even where speech is not legally obscene, the Court permits the government to regulate "offensive" sexual speech in ways that it could not regulate "offensive" political speech. ${ }^{10}$ The "offensive

${ }^{5}$ Jenkins v. Georgia, 418 U.S. 153, 157 (1974) (holding that it is constitutionally permissible to instruct 'jurors to apply 'community standards' without specifying which 'community").

${ }^{6}$ In Pope v. Illinois, 481 U.S. 497, 500-01 (1987), the Court held that in judging whether a work has "serious literary, artistic, political, or scientific value," the Court must apply a national "reasonable person" standard. Justice Scalia, concurring, noted the impossibility of this determination:

[I]n my view it is quite impossible to come to an objective assessment of (at least) literary or artistic value, there being many accomplished people who have found literature in Dada, and art in the replication of a soup can. Since ratiocination has little to do with esthetics, the fabled "reasonable man" is of little help in the inquiry, and would have to be replaced with, perhaps, the "man of tolerably good taste"-a description that betrays the lack of an ascertainable standard. If evenhanded and accurate decisionmaking is not always impossible under such a regime, it is at least impossible in the cases that matter. I think we would be better advised to adopt as a legal maxim what has long been the wisdom of mankind: De gustibus non est disputandum. Just as there is no use arguing about taste, there is no use litigating about it.

Id. at 504-05 (Scalia, J., concurring).

As Graham Hughes has written: "The disgust of the ordinary man is a dangerous guide for legislation, but judicial reliance upon notions of what disgusts the ordinary man is even more dangerous." Graham Hughes, Morals and the Criminal Law, 71 YALE L.J. 662, 677 (1962). For an amusing attempt to capture the nation's artistic taste, see Alexander Melamid et al., Painting by Numbers: The Search for a People's Art, 258 NATION 334 (1994).

${ }^{7}$ Brockett v. Spokane Arcades, Inc., 472 U.S. 491, 504-05 (1985) (holding that obscene matter must appeal to "shameful or morbid" sexual desires, not to a "normal interest in sex").

${ }^{8}$ Miller v. California, 413 U.S. 15, 24 (1973) (stating that state obscenity statutes must "be limited to works . . . which portray sexual conduct in a patently offensive way").

${ }^{9}$ See Texas v. Johnson, 491 U.S. 397, 414 (1989) ("If there is a bedrock principle underlying the First Amendment, it is that the government may not prohibit the expression of an idea simply because society finds the idea itself offensive or disagreeable.").

${ }^{10}$ See, e.g., Barnes v. Glen Theatre, Inc., 501 U.S. 560 (1991); FCC v. Pacifica 
speech" doctrine has developed, moreover, without any attempt to define what constitutes "offensive speech." If the "obscenity" doctrine rests on a definition that is internally incoherent, the "offensive speech" doctrine rests on no definition at all.

The claim that speech can be suppressed because "I know it when I see it," even if what the Court sees and knows cannot be intelligibly articulated, implies a peculiar relationship between the Court, the law, the community, and sexual speech. Ordinarily, attempts to regulate speech because of its content are subjected to exacting judicial scrutiny and require a compelling justification. When it comes to sexual expression, however, the state is not obliged to offer a compelling rationale, and the Court's decisions proceed by assertion rather than by logical reasoning. Like Justice Stewart's claim, the Court's doctrine suggests that sexual expression can (and perhaps must) be regulated by law even if (and precisely because) it is beyond reasoned discussion.

The peculiar relationship between law and sexual expression is perhaps best exemplified by the Indiana statute upheld in Barnes $v$. Glen Theatre, Inc., ${ }^{11}$ which required otherwise nude dancers to wear pasties and G-strings. At first glance, the law, upheld as a legitimate effort to shore up community morals, appears to serve little, if any, moral purpose; an exceedingly fine line distinguishes the wholly nude dancer from one attired in accordance with Indiana law. Indeed, for many, the scant covering required would likely make the dancers more sexy, not less. ${ }^{12}$ Indiana's insistence that this line be maintained-and the Court's approval of that line-suggests that what is ultimately at stake is not the prohibition of sex itself, but the assertion of the right (and capacity) to control its public representation.

Barnes reflects one of the most curious features of the regulation of sexual expression: at least as a matter of doctrine, public representations of sex are more subject to regulation than sexual behavior. This reverses the usual relationship between conduct and expression. While it is illegal, for example, to rob a bank, it is not illegal to publish a novel or make a movie about robbing a bank. Scholars and jurists have long debated over the precise point at which advocacy of illegal conduct should lose its First Amendment

Found., 438 U.S. 726 (1978); Young v. American Mini Theatres, Inc., 427 U.S. 50 (1976).

${ }^{11} 501$ U.S. 560 (1991).

12 See infra text accompanying notes 219-29. 
protection, but no one denies that a novelist, filmmaker or playwright has the right to depict illegal acts. Central to the First Amendment tradition is the notion that one has broader freedom in one's expression than in one's acts.

When it comes to sex, however, the rule is reversed. While sexual conduct is far from unregulated, ${ }^{13}$ constitutional law permits more extensive regulation of the public representation of sexual behavior than of the behavior itself. As construed by the Supreme Court, the First Amendment not only fails to protect representations of illegal sexual conduct; it permits the state to criminalize the representation of sexual conduct that is itself legal to engage in. Obscenity doctrine, for example, permits the proscription of prurient depictions of "patently offensive" sexual conduct, whether or not the underlying conduct is (or could be) unlawful. Similarly, while private nude dancing has never been banned, its public display may be extensively regulated. ${ }^{14}$

This Article seeks to address the questions raised by Justice Stewart's sentence, Barnes's image, and our culture's obsession with regulating the public representation of sex. Part $I$ argues that the conventional justifications for permitting the regulation of sexual expression-that sexual expression is not political, and is more akin to conduct than speech-are inadequate because they rest on overly simplistic notions of both sexuality and speech, and are contrary to core First Amendment principles.

In Part II, I suggest that the answer to why representations of sexual conduct are more subject to regulation than sex itself lies in the demarcation between public and private spheres. Laws

\footnotetext{
13 In particular, virtually all states prohibit prostitution and incest, while, as of 1994, only eighteen states have criminalized sodomy. Search of LEXIS, Codes Library, Allcde File (Sept. 21, 1994) (finding antisodomy statutes in Alabama, Arkansas, California, Connecticut, Georgia, Kansas, Kentucky, Maryland, Michigan, Minnesota, Missouri, New Mexico, New York, Ohio, Oklahoma, Oregon, South Dakota, and Utah). Prostitution, however, is generally tolerated despite the laws on the books, and sodomy is rarely prosecuted. I do not mean to understate the significance of laws regulating sexual behavior. Particularly with respect to prohibitions on homosexual sex, such laws are often "enforced" by less direct means than a criminal prosecution. Thus, government employers may fire gay employees, courts may deny gay and lesbian parents custody of their children, and private parties may "enforce" such prohibitions through gay-bashing and the like.

${ }^{14}$ Similarly, in Great Britain, "moral regulation in the 1970s took the form of the regulation of representations of sexuality as opposed to regulation of sexual behaviour." Lynda Nead, The Female Nude: Pornography, Art, and Sexuality, in SEX ExPOSED: SEXUALITY AND THE PORNOGRAPHY DEBATE 280, 285 (Lynne Segal \& Mary McIntosh eds., 1993) [hereinafter SEX EXPOSED].
} 
regarding sexual expression focus primarily on keeping sex out of the public sphere. Society targets for repression those who challenge the public/private line by making public sexual matters that the majority would prefer remained private. In fact, for some the essence of the obscene is its "publication" of private sexuality. The Court's sexual speech doctrine adopts and reinforces this public/private line. Obscenity in the home, for example, is constitutionally protected, ${ }^{15}$ while the sale or transportation of the same obscenity may be criminalized. ${ }^{16}$

Through a close reading of Bames, Part II then suggests that the Court's obsession with preserving the public/private line in sexual speech is not only contrary to, but has actually inverted two of the most basic principles of First Amendment jurisprudence. Ordinarily, the selective regulation of public conduct triggers heightened First Amendment scrutiny because it indicates an attempt to stifle communication; here, regulation of public conduct is permitted precisely because the conduct is public. And ordinarily the fact that the majority finds particular speech offensive is a reason to protect it; when it comes to sexual expression, however, community offense is the justification for suppression. I point to these inversions not so much to offer a doctrinal First Amendment defense of sexual speech-although I think a strong defense can be made-as to suggest that something else is going on. Analysis of the regulation of sexual expression must extend beyond doctrine to a cultural examination of the regulatory imperative.

Part III therefore asks why society places such emphasis on drawing public/private lines in matters of sexual expression. In part, no doubt, enforcement of these lines provides the illusion that we can control sexuality, a matter always in doubt. But where prior accounts have stressed the effects that sexual repression and

${ }^{15}$ See Stanley v. Georgia, 394 U.S. 557 (1969) (holding that the First Amendment bans criminalization of obscenity in the home).

${ }^{16}$ See United States v. 12 200-Ft. Reels of Super 8mm. Film, 413 U.S. 123 (1973) (holding that importation of obscene materials for private use may be prohibited); United States v. Reidel, 402 U.S. 351 (1971) (holding that mailing of obscene materials for private use may be criminalized).

Mere possession of child pornography may be constitutionally criminalized. See Osborne v. Ohio, 495 U.S. 103 (1990); New York v. Ferber, 458 U.S. 747 (1982). However, the rationale for prohibiting child pornography-the protection of children from necessarily nonconsensual sexual exploitation-distinguishes the regulation of child pornography from the regulation of other pornography. This Article does not address the issue of child pornography, but only addresses sexual expression made by, for, and with consenting adults. 
regulation have on the maintenance of social order, power, and productivity, I suggest that we consider the effects that such regulation has on sexuality itself.

Sexual expression, I propose, inevitably confounds society's attempts to regulate it. It subverts every taboo by making it a fetish. The forbidden is simultaneously eroticized. As a result, attempts to regulate sexual expression are doomed to failure; by creating taboos to transgress, regulation only adds to sexual expression's appeal. At the same time, by obsessively seeking to regulate and control sexual expression, we construct a sexuality that is in turn obsessed with transgression and taboo, often to the exclusion of other values. Our regulations endlessly reproduce a pornographic conception of sexuality, which in turn limits our ability to remake sexuality in a different light. Thus, those who are critical of the pornographic character of American sexuality-whether from an aesthetic, moral, or feminist perspective-may only reinforce that character if they continue to insist on a strategy of suppression.

\section{Regulating SEXUAL EXPREsSion: \\ THE TRADITIONAL JUSTIFICATIONS}

Two principal justifications have been advanced to explain why government should have a freer hand in regulating sexual expression than in regulating most other forms of expression. The first asserts that sexual speech is categorically different from political speech, and therefore of low value. The second claims that sexual expression is closer to conduct than speech, either because it fails to appeal to the intellect or because it subordinates women, and therefore does not deserve the full protection accorded other modes of expression. Neither justification is sufficient to explain the reduced constitutional status of sexual speech.

\section{A. Sex and Politics}

The central focus of the First Amendment tradition has been political speech. First Amendment lore begins with the criminalization of criticism of the government in the Sedition Act of 1798, which President Jefferson soundly repudiated by pardoning all convicted under it. ${ }^{17}$ The first important speech cases decided by

${ }^{17}$ In New York Times Co. v. Sullivan, 376 U.S. 254, 276-77 (1964), the Supreme Court relied upon the repudiation of the Sedition Act to justify imposing strict First Amendment restrictions on actions for libel of public officials. 
the Supreme Court involved antiwar protestors during World War I. ${ }^{18}$ Beginning between the World Wars and continuing well into the 1960s, most of the Court's leading First Amendment cases reviewed attempts to penalize Communist or Socialist Party members and fellow travelers for their speech or associations. ${ }^{19}$ The civil rights movement gave rise to another set of constitutional battles over political speech, as the First Amendment was invoked to guarantee the right to engage in sit-ins, ${ }^{20}$ to protect the news media's reporting on Southern officials' mistreatment of black citizens, ${ }^{21}$ and to enjoin state courts from using criminal laws to harass civil rights activists. ${ }^{22}$

${ }^{18}$ See Schenck v. United States, 249 U.S. 47 (1919) (upholding conviction under the Espionage Act of 1917 for circulating leaflets urging opposition to conscription); Debs v. United States, 249 U.S. 211 (1919) (upholding Espionage Act conviction of Socialist Party national leader for speech in which he praised persons convicted of aiding others to avoid induction into the armed services); Frohwerk v. United States, 249 U.S. 204 (1919) (upholding conviction for conspiracy to violate the Espionage Act by publishing articles in German language newspaper critical of war effort); Abrams v. United States, 250 U.S. 616 (1919) (upholding Espionage Act convictions of Russian immigrants who distributed leaflets calling for general strike to oppose war). The Supreme Court did decide speech cases prior to 1919, see generally David M. Rabban, The First Amendment in Its Forgotten Years, 90 YALE L.J. 514 (1981), but the World War I cases are seen as sowing the seeds of the speech-protective doctrine we know today. See David Cole, Agon at Agora: Creative Misreadings in the First Amendment Tradition, 95 YALE L.J. 857, 879-92 (1986).

${ }^{19}$ See, e.g., Gitlow v. New York, 268 U.S. 652 (1925) (upholding conviction under criminal anarchy statute of Socialist Party member for publishing "The Left Wing Manifesto," which advocated revolutionary socialism); Whitney v. California, 274 U.S. 357 (1927) (upholding conviction under California Criminal Syndicalism Act for membership in Communist Labor Party); Fiske v. Kansas, 274 U.S. 380 (1927) (overturning conviction under Kansas Criminal Syndicalism Act for soliciting members for Workers' Industrial Union); De Jonge v. Oregon, 299 U.S. 353 (1937) (overturning conviction under Criminal Syndicalism Law of Oregon for conducting a meeting of the Communist Party); Herndon v. Lowry, 301 U.S. 242 (1937) (overturning conviction under Georgia statute for inciting insurrection by recruiting members for the Communist Party); Dennis v. United States, 341 U.S. 494 (1951) (upholding Smith Act convictions of national Communist Party leaders); Yates v. United States, 354 U.S. 298 (1957) (overturning Smith Act convictions of Communist Party members); Scales v. United States, 367 U.S. 203 (1961) (upholding Smith Act conviction of Communist Party member merely for active membership in organization advocating illegal overthrow of government); United States v. Robel, 389 U.S. 258 (1967) (affirming dismissal of an indictment brought under Subversive Activities Control Act of a Communist Party member for engaging in employment at defense facility). See generally Marc Rohr, Communists and the First Amendment: The Shaping of Freedom of Advocacy in the Cold War Era, 28 SAN DIEGO L. REV. 1 (1991).

${ }^{20}$ See Brown v. Louisiana, 383 U.S. 131 (1966).

${ }^{21}$ See New York Times, 376 U.S. at 256.

${ }^{22}$ See Dombrowski v. Pfister, 380 U.S. 479 (1965). 
The Court's record in these political speech cases is on the whole not very inspiring. The Court's earliest First Amendment cases affirmed heavy prison sentences for pure political speech unrelated to any unlawful conduct. ${ }^{23}$ As late as 1951 the Court upheld convictions for mere membership in the Communist Party. ${ }^{24}$ And it was not until 1964 that the Supreme Court extended First Amendment protection to criticism of public officials. ${ }^{25}$

By the late 1960s, however, the Court adopted fairly strong speech-protective doctrines for political speech. In Brandenburg $v$. Ohio, ${ }^{26}$ the Court held that speech advocating unlawful conduct cannot be proscribed unless it is intended and likely to produce such conduct imminently-a test which the government can rarely meet. With New York Times Co. v. Sullivan ${ }^{27}$ and its progeny, the Court protected criticism of public officials and public figures, so long as the statements are not made with knowledge that they are false or with reckless indifference to the truth. And in Texas $v$. Johnson, ${ }^{28}$ the Court, overturning a conviction for burning the American flag, held that the government cannot prohibit symbolic political expression simply because it offends the majority of the public. Taken together, these cases offer significant safeguards for political speech.

The political speech cases are generally seen as the core of First Amendment doctrine. They reflect the principles that government may not determine truth or propriety in the realm of public discourse, that a free and vigorous public debate is crucial to the process of deliberative self-government, that the purpose of the First Amendment is to protect the rights of dissidents and minority voices, and that the best check on the abuse of power is the light of public scrutiny and criticism. It is cases and principles like these that have led law professors to call for dancing in the streets. ${ }^{29}$

But the First Amendment also has another story. This story has a much shorter time span, ranging from the 1950 s to the present.

${ }^{25}$ See Debs v. United States, 249 U.S. 211 (1919).

${ }^{24}$ See United States v. Dennis, 341 U.S. 494 (1951).

${ }^{25}$ See New York Times, 376 U.S. at 292.

26395 U.S. 444 (1969).

27376 U.S. 254 (1964); see also Curtis Publishing Co. v. Butts, 388 U.S. 130 (1967) (extending First Amendment protection to criticisin of "public figures").

${ }^{28} 491$ U.S. 397 (1989).

${ }^{29}$ See Harry Kalven, Jr., The New York Times Case: A Note on "The Central Meaning of the First Amendment, 1964 SUP. CT. REV. 191, 221 n.125 (describing the reaction of Alexander Meiklejohn to New York Times Co. v. Sullivan). 
It concerns the regulation of sexual expression, including obscenity, offensive speech, and public nudity. The Court's doctrine in this area could not be more different from its political speech jurisprudence. In the realm of sexual expression, the fact that a majority of the community finds speech offensive or immoral is often sufficient to justify its regulation. As Justice Stevens explained, Voltaire's remark that "I disapprove of what you say, but I will defend to the death your right to say $\mathrm{it}^{\mathrm{n30}}$ does not apply to the subject of sex.

The First Amendment thus has two significant traditions that coexist in conspicuous tension. To account for that tension, some members of the Supreme Court have asserted a qualitative difference between sexual and political speech. In Young v. American Mini Theatres, Inc., ${ }^{31}$ for example, Justice Stevens maintained that content-based regulation of sexual expression is permissible because "society's interest in protecting this type of expression is of a wholly different, and lesser, magnitude than the interest in untrammeled political debate." ${ }^{32}$ As he put it, in terms that echoed Justice Stewart's "I know it when I see it":

Whether political oratory or philosophical discussion moves us to applaud or to despise what is said, every schoolchild can understand why our duty to defend the right to speak remains the same. But few of us would march our sons and daughters off to war to preserve the citizen's right to see "Specified Sexual Activities" exhibited in the theaters of our choice. ${ }^{33}$

Because it is deemed less valuable, sexual speech has a different location on "the hierarchy of First Amendment values," and, unlike political expression, may be suppressed in certain contexts. ${ }^{34}$ As the Court recently said of nude dancing, it is "within the outer perimeters of the First Amendment, though we view it as only marginally so." 35

${ }^{30}$ S.G. TALIENTYRE, THE FRIENDS OF VOLTAIRE 199 (1907) (quoted in Young v. American Mini Theatres, Inc., 427 U.S. 50, 63 (1976)).

${ }^{31} 427$ U.S. 50 (1976).

32 Id. at 70 .

${ }^{33} I d$.

${ }^{34}$ FCC v. Pacifica Found., 438 U.S. 726, 746 (1978).

${ }^{35}$ Barnes v. Glen Theatre, Inc., 501 U.S. 560, 566 (1991) (plurality); see also id. at n.3 (Souter, J., concurring) (stating that "protection of sexually explicit expression may be of lesser societal importance than the protection of other forms of expression"); City of Renton v. Playtime Theatres, Inc., 475 U.S. 41, 49 n.2 (1986) (noting that society's interest in protecting sexual speech is of a lesser magnitude than the interest in protecting political speech). 
While a majority of the Supreme Court did not expressly adopt Justice Stevens's view in American Mini Theatres, the Court's First Amendment doctrine nonetheless appears to depend upon the claim that sexual expression is not political. ${ }^{36}$ The Court allows government to regulate sexual expression in ways that it flatly forbids for political speech. Sexual expression can be zoned to remote parts of town, ${ }^{37}$ denied access to the airwaves until late at night, ${ }^{38}$ and even criminally suppressed if the community finds it simultaneously appealing, offensive, and valueless. ${ }^{39}$ Most recently, nude dancers can be required to wear pasties and a G-string to uphold the community's morals. ${ }^{40}$ By contrast, the state is generally barred from regulating political expression, even if an overwhelm-

${ }^{36}$ In American Mini Theatres, Justice Stevens wrote the opinion of the Court upholding a zoning ordinance imposed only on adult movie theaters. See 427 U.S. at 52. However, four Justices dissented, see id. at 84 (Stewart, Brennan, Marshall, Blackmun, J., dissenting), and Justice Powell wrote separately to note that he disagreed with Justice Stevens's view "that nonobscene, erotic materials may be treated differently under First Amendment principles from other forms of protected expression." Id. at 73 n.1 (Powell, J., concurring); see also Pacifica, 438 U.S. at 761 (Powell, J., concurring) (voting to uphold FCC restriction on hours when "indecent" material could be broadcast, but writing separately to state that "in my view, the result in this case does not turn on whether Carlin's monologue, viewed as a whole, or the words that constitute it, have more or less 'value' than a candidate's campaign speech").

In both American Mini Theatres and Pacifica, Justice Powell, who cast the decisive votes, insisted that he did not accept Justice Stevens's view that sexual expression is less valuable than political expression, and therefore less worthy of First Amendment protection. See 427 U.S. at 73 n.1; 438 U.S. at 761. At the same time, however, Powell voted to uphold the regulations at issue in both cases. Justice Brennan concluded that if Powell meant what he said-that there should be no distinction between political and sexual expression-his analysis would permit government to regulate political speech in the same manner that it has regulated sexual speech. See Pacifica, 438 U.S. at 772 n.6 (Brennan, J., dissenting). Under Pacifica the FCC could ban "offensive" political expression from the airwaves while children might be listening. And under American Mini Theatres a town council could zone dissident political bookstores or speakers to particular areas of town if it concluded that they attracted an undesirable clientele that caused "secondary" problems. Since it is extremely unlikely that Powell would have upheld such regulations of politically offensive speech, he must have been relying, despite his demurrers, on an unspoken distinction between political and sexual speech.

${ }^{37}$ See City of Renton, 475 U.S. at 43; American Mini Theatres, 427 U.S. at 72-73.

${ }^{38}$ See Pacifica, 438 U.S. at 750.

${ }^{39}$ See Miller v. California, 413 U.S. 15, 24 (1973). Under the Miller standard, a jury must find speech to both appeal to the prurient interests and be patently offensive in order to find it obscene. In addition, the jury must find that the work lacks any serious literary, artistic, political, or scientific value.

${ }^{40}$ See Barnes v. Glen Theatre, Inc., 501 U.S. 560, 563 (1991). 
ing majority of the public finds it offensive, immoral, and without redeeming value. ${ }^{41}$

Perhaps the most extreme version of such a hierarchy of political and sexual speech was proposed by the Solicitor General in Roth $v$. United States, ${ }^{42}$ who suggested the following scale of value:

political speech

religious

economic

scientific

general news and information

social and historical commentary

literature

art

entertainment

music

humor

commercial advertisements

gossip

comic books

epithets

libel

obscenity

profanity

commercial pornography. ${ }^{43}$

The Court did not accept this absurdly specific categorization, which would have required explaining, among other things, why gossip is less valuable than humor but more valuable than comic books. But the Court's obscenity doctrine nonetheless rests on a categorical assertion that at least some sexually explicit speech is different from and less valuable than political speech. Justice Brennan's decision in Roth held that the First Amendment was designed to assure an unfettered exchange of ideas "having even the slightest redeeming. social importance," but found that "implicit in the history of the

${ }^{41}$ See Texas v. Johnson, 491 U.S. 397, 414 (1989) (asserting that "if there is a bedrock principle underlying the First Amendment, it is that Government may not prohibit the expression of an idea simply because society finds the idea itself offensive or disagreeable"); Hustler Magazine v. Falwell, 485 U.S. 46, 50 (1988) (extending First Amendment protection to speech that is patently offensive and intended to inflict emotional injury); Cohen v. California, 403 U.S. 15, 21 (1971) (protecting, under the First Amendment, the right to wear a jacket bearing the message, "Fuck the Draft").

42354 U.S. 476 (1957).

${ }^{43}$ Brief for the United States at 29, Roth v. United States, 354 U.S. 476 (1957) (No. 582). 
First Amendment is the rejection of obscenity as utterly without redeeming social importance. ${ }^{\text {M4 }}$ Under current obscenity doctrine, once sexual speech is found to have no "serious literary, artistic, political, or scientific value," it may be criminally prohibited if the community finds it shamefully or morbidly prurient and patently offensive. ${ }^{45}$

Thus, the Court's strategy for resolving the tension between sexual and political speech is to assert an objective difference in the character of the speech. ${ }^{46}$ That categorical assertion is expressly built into the obscenity doctrine-political speech is by definition not obscene-and implied in the "offensive speech" doctrine (because one cannot imagine the Court permitting zoning of politically offensive bookstores). But the assertion is neither descriptively accurate nor normatively justified.

As a descriptive matter, the political significance of sexual expression is revealed every day. Sexuality and its expression have become heated political issues in virtually every arena, from local school board disputes over sex education, ${ }^{47}$ to state anti-gay legislative efforts, ${ }^{48}$ to conservative and feminist attempts to

4 Roth, 354 U.S. at 484.

${ }^{15}$ Miller v. California, 413 U.S. 15, 24 (1973).

${ }^{16}$ Some commentators have embraced this justification. Cass Sunstein, for example, argues that pornography may be regulated consistent with the First Amendment because it is "low value" speech, in part because its subject is far afield from political speech. See Cass R. Sunstein, Pornography and the First Amendment, 1986 DUKE L.J. 589, 602-05.

${ }^{17}$ See, e.g., Mary C. Dunlap, Sexual Speech and the State: Putting Pornography in Its Place, 17 GoldEN GATE U. L. REV. 359, 369-70 (1987) (describing the Californian debate over sex education guidelines in 1986 and 1987).

${ }^{48}$ On November 3, 1992, Colorado voters passed Amendment 2, which prohibits the enactment of ordinances against discrimination on sexual orientation grounds and repealed gay rights ordinances in Aspen, Boulder, and Denver. See Legislator Offering Measure to Repeal Anti-Gay Vote, Reuters Limited, December 7, 1992, available in LEXIS, Nexis Library, REUNA File.

In Oregon, the Oregon Citizens' Alliance (OCA) promoted Ballot Measure 9, a 1992 initiative that would have removed homosexual materials from schools and decreed homosexuality to be "wrong, abnormal, unnatural and perverse." Melinda Bargreen, A Big Round of Jeers for These "Honorees," SEATTLE TIMES, Sept. 26, 1993, at F1. Although the referendum did not pass, 16 Oregon cities and counties have adopted local OCA-sponsored legislation that prohibits any government recognition or promotion of homosexuals' rights or freedom from discrimination. In August 1993, the Oregon legislature passed a bill prohibiting these local ordinances but the law is now being challenged by the OCA. See Keizer Approves Anti-Gay Measure, UPI, Nov. 10, 1993, available in LEXIS, Nexis Library, UPI File; Oregon Cities Adopt Anti-Gay Rights Measures, Daily Lab. Rep. (BNA) No. 217, at D-20. (Nov. 12, 1993), available in LEXIS, Nexis Library, Curnws File. The OCA has also attempted to start anti-gay 
regulate pornography, ${ }^{49}$ to attacks on artists who use sexual themes in their work, ${ }^{50}$ to debates over "family values" in national presidential campaigns. ${ }^{51}$ As Kendall Thomas has noted:

Discussions of issues regarding sexuality that were conducted in the rhetoric of privacy have increasingly come to be posed as public issues about relations of power and domination. Struggles over sexuality and its social meaning are now firmly fixed on our national political agenda. ${ }^{32}$

The efforts of politicians and interest groups to censor sexual expression only underscore the political significance of such expression. The feminist initiative to regulate pornography, for example, is directly predicated on pornography's political message-the subordination and objectification of women. ${ }^{53}$ Indeed, the collapse of a descriptively persuasive distinction between political and sexual speech may be more generally attributed to society's widespread adoption of an early feminist insight, now a truism: the personal is political.

The distinction between sexual and political speech also makes little sense in light of First Amendment principles. The only rationale the Court has offered is that society finds sexual speech less valuable than political speech. But the First Amendment

initiatives in Washington, Idaho, and California. See Bargreen, supra, at F1.

${ }^{19}$ See CATHARINE MACKINNON, ONLY WORDS 9 (1993) (claiming that "[p]rotecting pornography means protecting sexual abuse as speech").

${ }^{30}$ See infra notes 78-84, 88-93 and accompanying text.

51 Both the Republican and Democratic parties appealed to "family values" in the 1992 presidential campaign. See Sheryl McCarthy, GOP Values: Getting Mean, NEWSDAY (N.Y.), Aug. 19, 1992, at 20; Andrew Rosenthal, What's Meant and What's Mean in the "Family Values" Battle, N.Y. TIMEs, July 26, 1992, § 4, at 1. At the 1992 Republican Convention, Pat Buchanan delivered a "family values" speech that directly attacked gay rights, abortion, and feminism. See Tony Freemantle, Buchanan: Soul of U.S. is at Stake, HOUSTON CHRON., Aug. 18, 1992, at B1.

${ }^{52}$ Kendall Thomas, Beyond the Privacy Principle, 92 Colum. L. REv. 1431, 1510 (1992) (citations omitted). Lynne Segal has similarly written: "Two things, at least, are clear today. Sexuality is a battleground within mainstream politics as never before in the twentieth century; and attitudes towards homosexuality are on the front-line." Lynne Segal, Slow Motion: Changing Masculinities, Changing Men 160(1990).

For interesting accounts of the interconnections of pornography and political dissent in 16th to 18th century Europe, see Lynn Hunt, Introduction to THE INVENTION OF PORNOGRAPHY: OBSCENITY AND THE ORIGINS OF MODERNITY, 15001800, at 9 (Lynn Hunt ed., 1993). The United States, however, appears to lack such a tradition; the use of sexual speech for expressly political purposes is a much more recent phenomenon, largely traceable to the "coming out" of gays and lesbians. See infra notes 79-82 and accompanying text.

5s See American Booksellers Ass'n, Inc. v. Hudnut, 771 F.2d 323, 328-29 (7th Cir. 1985), aff'd, 475 U.S. 1001 (1986). 
precludes precisely such value judgments; it is most needed to protect that speech which the majority finds most offensive, least valuable, and therefore least worthy of protection. ${ }^{54}$ Thus, to suggest that sexual expression may be censored because "we" find it less important than other speech is to deny First Amendment protection exactly where it is needed.

\section{B. Regulating Pormography as Sex Aid or Subordination}

Several proponents of the regulation of sexual expression have advanced a different rationale for according sexual expression diminished constitutional protection, asserting that it is noncognitive. Frederick Schauer, this theory's most ardent proponent, argues that at least some sexual expression-hard-core pornography-deserves no First Amendment protection because it is "designed to produce a purely physical effect." ${ }^{55}$ He likens hardcore pornography to a sexual aid, and suggests that since a vibrator would not receive First Amendment protection, neither should pornography. ${ }^{56}$ This argument rests on a purported distinction

${ }^{54}$ See FCC v. Pacifica Found., 438 U.S. 726, 745 (1978) ("[T] may find speech offensive is not a sufficient reason for suppressing it. Indeed, if it is the speaker's opinion that gives offense, that consequence is a reason for according it constitutional protection."); STEVEN H. SHIFFRIN, THE FIRST AMENDMENT, DEMOGRACY, AND ROMANCE 108 (1990) (arguing that the First Amendment is designed to protect dissenters from majoritarian values).

${ }^{55}$ Frederick Schauer, Speech and "Speech"-Obscenity and "Obscenity": An Exercise in the Interpretation of Constitutional Language, 67 GEO. L.J. 899, 922 (1979) [hereinafter Schauer, Speech]; see U.S. DEP'T OF JUSTICE, 2 ATTORNEY GENERAL's COMMISSION ON PORNOGRAPHY, FINAL REPORT 1275 (1986) [hereinafter ATTORNEY GENERAL] (drafted by Schauer) ("Obscene materials lack cognitive content . . . ."); Frederick Schauer, Response: Pornography and the First Amendment, 40 U. PrTT. L. REV. 605, 608 n.14 (1979) ("Direct sexual excitement can hardly be said to contribute to the marketplace of ideas ....."); see also John M. Finnis, "Reason and Passion": The Constitutional Dialectic of Free Speech and Obscenity, 116 U. PA. L. REV. 222, 227 (1967) (obscenity may be censored because it "pertains, not to the realm of ideas, reason, intellectual content and truth-seeking, but to the realm of passion, desires, cravings and titillation"); Cass R. Sunstein, Pormography and the First Amendment, 1986 DUKE L.J. $589,603-04,612-17$ (arguing that pornography is regulable low-value speech because it is noncognitive, does not intend to communicate an idea, is far afield from political speech).

${ }^{56}$ Schauer argues:

The pornographic item is in a real sense a sexual surrogate. It takes pictorial or linguistic form only because some individuals achieve sexual gratification by those means. . . . Consider further rubber, plastic, or leather sex aids. It is hard to find any free speech aspects in their sale or use. If pornography is viewed merely as a type of aid to sexual satisfaction, any distinction between pornography and so-called "rubber products" is meaningless. 
between communication designed to appeal to the intellect and communication that generates sexual arousal.

Upon examination, however, this distinction collapses from both sides. On the one hand, it exaggerates the intellectual character of the nonsexual speech that the First Amendment fully protects. ${ }^{57}$ While one can understand why a law professor might find appealing a claim that only speech that speaks to the intellect should be protected, such a claim presumes an extremely parsimonious view of communication. As Paul Chevigny has eloquently demonstrated, the processes of persuasion, learning, and knowing are by no means purely intellectual or rational. ${ }^{58} \mathrm{We}$ comprehend the world as much through intuitive judgments, emotional and aesthetic responses, and stereotypic beliefs and images as through purely rational deductions. ${ }^{59}$

Some of the most influential forces in our culture do not make an argument or appeal to the intellect: music, visual art, and a great deal of advertising (including political advertising) contribute to the "marketplace of ideas" through sound, imagery, and nonrational appeals to passion and desire. It would be difficult to say that a Madonna concert makes a strictly rational "argument," yet Madonna's "communications" have had at least as great an effect on our cultural and political life as most books of analytic philosophy or political science. Poets and philosophers alike have recognized and celebrated the "affective" power of art to produce sublime, nonrational responses. ${ }^{60}$ Thus, one cannot restrict First Amend-

Schauer, Speech, supra note 55, at 922-23.

${ }^{57}$ In Texas v. Johnson, the Supreme Court rejected the dissent's argument that flag burning should not be protected because it is merely an "inarticulate grunt." 491 U.S. 397, 432 (1989) (Rehnquist, C.J., dissenting) ("Far from being a case of 'one picture being worth a thousand words,' flag burning is the equivalent of an inarticulate grunt or roar that, it seems fair to say, is most likely to be indulged in not to express any particular idea, but to antagonize others.").

${ }^{5 s}$ See Paul Chevigny, Pornography and Cognition: A Reply to Cass Sunstein, 1989 DUKE L.J. 420; see also Stephen G. Gey, The Apologetics of Suppression: The Regulation of Pornography as Act and Idea, 86 MICH. L. REv. 1564, 1586-94 (1988) (exploring logical inconsistencies in Schauer's view of what is and is not speech); Susan E. Keller, Viewing and Doing: Complicating Pornography's Meaning, 81 GEO. L.J. 2195, 2211 (1993) ("Chevigny maintains that so-called rational thought is actually accomplished by intuition ... much the way he asserts pornography works.").

${ }^{59}$ See Chevigny, supra note 58, at 423-26.

${ }^{60} \mathrm{John}$ Keats's poem, On First Looking Into Chapman's Homer, is just one example:

Much have I travelled in the realms of gold,

And many goodly states and kingdoms seen;

Round many western islands have I been 
ment protection to the rational or "cognitive" without ignoring what works as persuasion in public discourse and vastly expanding the government's power to censor.

On the other side of the balance, the argument that sexual speech is "noncognitive" because it is designed to produce a physical effect is predicated on an impoverished view of sexuality. The argument implies that at base, sex is purely physical. But sex cannot be stripped of its expressive elements: "Sexuality is as much about words, images, ritual and fantasy as it is about the body: the way we think about sex fashions the way we live it. ${ }^{n 1}$

Moreover, even if sex could be treated as purely physical, Schauer's argument that pornography is no more than a sex aid implies that pornographic images somehow work directly on the sexual organs without any cognitive processing. If this were the case, any depiction of nudity or sexual organs would be pornographic; there would be no difference between an anatomy textbook and Penthouse. In fact, pornography "works" only because (and to the extent that) it plays upon fantasies and narratives which the reader,

Which bards in fealty to Apollo hold.

Oft of one wide expanse had I been told

That deep-browed Fomer ruled as his demesne:

Yet did I never breathe its pure serene

Till I heard Chapman speak out loud and bold:

Then felt I like some watcher of the skies

When a new planet swims into his ken;

Or like stout Cortez, when with eagle eyes

He stared at the Pacific-and all his men

Looked at each other with a wild surmise-

Silent, upon a peak in Darien.

John Keats, On First Looking Into Chapman's Homer, reprinted in THE NEW OXFORD BOOR OF ENGLISH VERSE 602 (Helen Gardner ed., 1972).

Shakespeare's Hamlet had a similar insight, although from a somewhat more skeptical perspective:

Is it not monstrous that this player here,

But in a fiction, in a dream of passion,

Could force his soul so to his own conceit

That from her working all his visage wanned,

Tears in his eyes, distraction in his aspect...

[A]nd all for nothing!

William Shakespeare, Hamlet act 2, sc. 2 (John D. Wilson ed., Cambridge University Press 2d ed. 1936); see also PLATO, THE REPUBLIC 277-86 (Allan Bloom trans., 1968) (arguing that poets create unreal images which stimulate our emotions at the expense of our reason). See generally IMMANUEL KANT, CRITIQUE OF JUDGEMENT (J.H. Bernard trans., 2d ed. rev. 1914).

${ }^{6 l}$ JEFFrEY WEEKS, SEXUALTTY AND ITS Discontents: MEANINGS, MYTHS AND MODERN SEXUALITIES 3 (1985). 
viewer, or listener finds arousing. Sexual expression, like human sexuality itself, cannot be "purely physical." Rather, it is deeply and inextricably interwoven with our identities, our emotions, our upbringing, our relationships to other human beings, and the everchanging narratives and images that our community finds stimulating. ${ }^{62}$

Thus, the argument that sexual expression can be usefully distinguished from political speech because it lacks "cognitive" appeal is insupportable. Both political and sexual expression work in rational and irrational ways and contribute to our culture, our ideology, and our individual and collective identities through their rational and irrational communicative content.

A related argument, advanced by antipornography feminists, maintains that pornography-defined generally as "the graphic sexually explicit subordination of women through pictures and/or words ${ }^{n 63}$-can be regulated not because it triggers a physical response, but because it is conduct. In Catherine MacKinnon's view, pornography "is a form of forced sex," and "[ $t]$ he experience of the (overwhelmingly) male audiences who consume pornography is therefore not fantasy or simulation or catharsis but sexual reality: the level of reality on which sex itself largely operates." ${ }^{64}$ In this view, pornography does not merely advocate violence toward women, it is violence toward women, and therefore can be regulated without

${ }^{62}$ The "purely physical" act of sex itself is also of course deeply imbued with expressive meaning. Consider, for example, Richard Goldstein's discussion of homosexual sex:

[F]or many gay men, fucking satisfies a constellation of needs that are dealt with in straight society outside the arena of sex. For gay men, sex, that most powerful implement of attachment and arousal, is also an agent of communion, replacing an often hostile family and even shaping politics. It represents an ecstatic break with years of glances and guises, the furtive past we left behind.

Richard Goldstein, Heartsick: Fear and Loving in the Gay Community, VILLAGE VoIcE, June 28, 1983, at 9, 12.

${ }^{63}$ Andrea Dworkin, Against the Male Flood: Censorship, Pornography, and Equality, 8 HARV. WOMEN's L.J. 1, 25 (1985) (presenting Model Anti-Pornography Law).

6t CATHARINe A. MACKInNON, FEMINISM UNmodified: Discourses ON LIFE AND LAW 148-49 (1987) (citations omitted); see also MACKINNON, supra note 49, at 19 ("Sooner or later, in one way or another, the consumers [of pornography] want to live out the pornography further in three dimensions. Sooner or later, in one way or another, they do."); $i d$. at 28 ("In terms of what men are doing sexually, an audience watching a gang rape in a movie is no different from an audience watching a gang rape that is re-enacting a gang rape from a movie, or an audience watching any gang rape."); id. at 13 ("Social inequality is substantially created and enforced-that is, done-through words and images."). 
First Amendment concerns. This claim collapses the distinction between the representation of subordination and subordination itself, and relies on the legitimacy of regulating violent conduct as an argument for regulating pornography.

Like Schauer's argument, MacKinnon's claim both proves too much and explains too little. It proves too much because the representation of subordination is by no means limited to pornography. The subordination and objectification of women can be found in virtually every form of expression, from commercial advertising to rap music to fashion magazines to best-selling novels to television sitcoms. Indeed, in a culture characterized by inequality, it would be surprising if inequality were not expressed across all media. Many of these forms of expression, moreover, eroticize hierarchy and subordination, just as some pornography does. These "aboveground" media may well be more influential in perpetuating inequality than pornography, because they are more widely disseminated and less subject to social opprobrium. ${ }^{65}$

If the concern is subordination, why focus only on "graphic sexually explicit" messages of subordination? What about implicit sexual messages of subordination? And what about nonsexual messages of subordination? Why should these be any less subject to the censor's reach? As Robert Skipper has noted:

Inequality can and has been romanticized, glorified, celebrated, patriotized, totemized, sacralized, proselytized, and aestheticized. Each one of these techniques involves positively associating inequality with a powerful action-guiding emotion. Why, then, is the eroticization of inequality in a class by itself of tactics to be censored? ${ }^{66}$

MacKinnon's argument offers little justification for drawing the line at pornography and, accordingly, would appear to justify broad government regulation of speech that affirms or represents women's subordination. ${ }^{67}$

${ }^{65}$ See Carlin Meyer, Sex, Sin and Women's Liberation: Against Porn-Suppression, 72 TEX. L. REv. 1097, 1172-83 (1994) (arguing that mainstream images of women's subordination are more prevalent and influential than pornography).

${ }^{66}$ Robert Skipper, Mill and Pornography, 103 ETHIcs 726, 728 (1993).

${ }^{67}$ For example, Mackinnon argues:

When equality is recognized as a constitutional value and mandate, the idea that some people are inferior to others on the basis of group membership is authoritatively rejected as the basis for public policy. This does not mean that ideas to the contrary cannot be debated and expressed. It should mean, however, that social inferiority cannot be imposed through any 
Mackinnon's view of pornography also explains too little about sex. It portrays pornography monolithically and presupposes that the antiporn feminists' reading of pornography is pornography's only possible meaning. In fact, like most modes of representation, pornography has different effects on different readers. For some, pornography is revolting on moral or religious grounds. Others find it boring. Some'will see it, as Mackinnon does, as a source of inequality. For still others, pornography may provide a "safe" way to play out fantasies they would not want to act out in reality, whether because acting out the fantasies would result in injury or insult to self or others, because of the danger of sexually transmitted diseases, or simply because of shyness or repression. Pornography no doubt will incite some to engage in dangerous or violent sexual practices, just as violent novels or films may spark some to violence, but it is by no means evident that such a response is the norm, much less the only response. ${ }^{68}$ Indeed, some feminists report that they are aroused by images and fantasies of female submission, even though in reality they clearly would not desire to adopt such roles. ${ }^{69}$ Pornography and sexual fantasy are far more

means, including expressive ones.

MACKINNON, supra note 49, at 108. But MacKinnon does not tell us how to distinguish between debating or expressing social inferiority and "imposing" social inferiority through "expressive" means. Advertisements and mainstream television shows "express" subordinate roles for women at least as pervasively as "graphic sexually explicit" pornography. Mackinnon offers no explanation for why making the same message graphically sexually explicit transforms it from mere expression of an idea into the imposition of inequality. The strength of MacKinnon's work lies in revealing the pervasive role that expression plays in reinforcing inequality, but that very insight makes the distinction she attempts to draw elusive.

${ }^{68}$ See generally Keller, supra note 58, at 2215-22 (describing differing responses to pornography). Indeed, studies indicate that a significant percentage of viewers of pornographic videos are women and there is little evidence that women are enacting the sexual violence depicted:

[I]t is estimated that [women] now account for 40 per cent of all X-rated video rentals, and a Redbook magazine survey confirms that nearly half the women surveyed regularly watch porn films. Another poll estimates that two out of three women in Germany and France watch video porn regularly.

Anne McClintock, Gonad the Barbarian and the Venus Flytrap: Portraying the Female and Male Orgasm, in SEX EXPOSED, supra note 14, at 111, 130. A recent University of Chicago survey reported that $23 \%$ of men and $11 \%$ of women admitted to having purchased or rented an X-rated video during the past year. See EDWARD O. LAUMANN

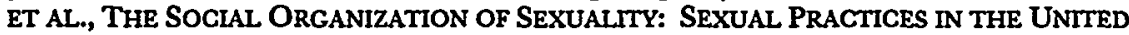
STATES 135 (1994).

${ }^{69}$ See Lynne Segal, Sweet Sorrows, Painful Pleasures: Pornography and the Perils of Heterosexual Desire, in SEx EXPOSED, supra note 14, at 65, 71; Duncan Kennedy, Sexual Abuse, Sexy Dressing and the Eroticization of Domination, 26 NEW ENG. L. REv. 1309, 
complex than the antiporn feminists suggest, and cannot be reductively equated with male domination over and violence towards women. ${ }^{70}$

This is not to say that Mackinnon and the antipornography feminists are wrong about one of the central messages of much pornography. MacKinnon's work in particular has played a key role in moving the debate about pornography beyond concerns of morality and focusing instead on the powerful messages of sexual subordination that are often implicit and explicit in pornography. Moreover, MacKinnon correctly identifies sex as a central element in unequal relations between men and women, and has incisively revealed the many ways in which this most "private" of human practices, central to our individual identities, reinforces roles of dominance and subordination. But it does not follow from that insight that pornography is only what MacKinnon sees, any more than it is only what Justice Stewart sees.

\section{$* * *$}

Each of these justifications for regulating sexual expression attempts in its own way to categorically distinguish sexual expression from other speech, and argues that because of this distinction, sexual speech does not deserve the usual measure of First Amendment protection. The political-sexual distinction maintains that while sexual expression may be speech, it is of low value. Schauer and MacKinnon go further, suggesting that certain sexual expression should not be treated as speech at all, but as a form of noncognitive sexual aid or direct subordination, regulable as conduct. All of these arguments share with Justice Stewart's "I know it when I see it" a common failing: they deny the multiplicity of meanings that sexual expression can convey, and their arguments rest on that reductivism.

These accounts of sexual speech themselves mark an attempt to "control" sexual expression, by neatly confining it to a distinct

1391-92 (1992) (hypothesizing that men and women may have fantasies of submission and/or domination when they are anxious or insecure about asserting themselves).

${ }^{70}$ See Jonathan Elmer, The Exciting Conflict: The Rhetoric of Pornography and AntiPornography, 8 CuLTURAL CRITIQUE 45 (1987-88) (analyzing reductivist rhetoric of antipornography feminist critics); see also Linda Williams, Pornographies on/Scene: Or Diffrent Strokes for Diffrent Folks, in SEX EXPOSED, supra note 14, at 233 (describing the proliferation of pornographies, including lesbian, gay, bisexual, sadomasochistic, and hermaphroditic). 
category of communication. So confined, we can suppress it without sacrificing First Amendment freedoms for more "important" categories of speech. So confined, we can justify its regulation with arguments that would be plainly unacceptable if applied across the board to all forms of speech. So confined, we can "know it when we see it," even if we cannot intelligibly define it.

The problem is that sexual speech cannot be so confined. That is why Justice Stewart could not define hard-core pornography, why the Court itself has never tried to define sexually offensive speech, why MacKinnon cannot explain her focus on "graphic sexually explicit" messages of subordination, and why the Court's test for obscene speech is incoherent. The sexual/political speech distinction and the sexual-speech-as-conduct argument can only be asserted, not explained. Sexual speech eludes our attempts to reduce it to a carefully bounded category. Yet precisely for that reason-indeed, for reason itself-we feel compelled to try to control it. Part II will examine the peculiar ways in which this compulsion to control manifests itself in law.

\section{The Politics of SeXual SPeEch Regulation: POLICING THE "INVASION OF PUBLICITY"}

The classic explanation for the differential treatment of sexual speech is that it is categorically less valuable than other speech. I suspect, however, that sexual expression is granted reduced constitutional protection not because it is less important but because it is more threatening. Many of the most heated political controversies in recent times have concerned sexual expression. The very energy that government and various interest groups have devoted to the repression of sexual expression reveals the threat it poses. The threat appears to be greatest when sexual expression challenges the line between the public and private spheres. When sex, which is generally considered a private matter, invades the public sphere, it sparks frenzied efforts to put it back in its private place. A review of recent incidents of sexual repression reveals the extent to which the regulatory impulse consists of maintaining a public/private line with respect to sexual matters. 


\section{A. Social Repression of Public Sexual Expression}

All sexual expression at least potentially challenges the public/ private line. Pornography by definition contravenes the lines society has drawn between public and private, by "representing" sex, which is understood as private, for public consumption. Its most ardent opponents object to pornography for precisely this reason. For example, the 1986 Attorney General's Commission on Pornography, known as the "Meese Commission," stated that its concern was limited to public distribution and display of pornography. To the conservatives who dominated the Commission, "[e]ven images of morally approved marital sexuality were judged 'degrading,' since public viewing of what should be a private experience degraded the couple and the sanctity of marriage. ${ }^{m 1}$

Commission member Father Bruce Ritter made this connection most transparently in a separate statement he attached to the Report, entitled "Pornography and Privacy." Quoting George Bernard Shaw's complaint that "[a]n American has no sense of privacy," Ritter wrote:

If there is one single lesson we have learned from studying the "problem of pornography," it may simply be that Mr. Shaw's acid observations on American privacy may finally be coming true. Commercially produced material, regularly distributed to millions of Americans, shows other Americans, in explicit photographic detail, engaged in every variety of sexual intercourse. What might have been considered at one time the most private of human activities is now a matter not simply for public discussion but for graphic public display. ${ }^{72}$

${ }^{11}$ Carole S. Vance, Negotiating Sex and Gender in the Attorney General's Commission on Pornography, in SEX EXPOSED, supra note 14, at 29, 37. The Commission Report stated:

Even insofar as [nonviolent and nondegrading] sexually explicit material ... is not perceived as harmful for the messages it carries or the symbols it represents, the very publicness of what is commonly taken to be private is cause for concern. . . . Here the concern is with the preservation of sex as an essentially private act, in conformity with the basic privateness of sex long recognized by this and all other societies.... [A]s soon as sex is put on a screen or put in a magazine it changes its character, regardless of what variety of sex is portrayed.

1 ATTORNEY GENERAL, supra note 55, at 340 (citations omitted). The members of the Commission could not agree, however, on whether this harm alone was sufficient to justify regulation of such expression. See $i d$. at 341.

721 ATTORNEY GENERAL, supra note 55, at 117 (statement of Father Bruce Ritter); see also id. at 36 (statement of Diane D. Cusack) ("We have a phenomenon today, in 
This understanding is not unique to the United States. England's Williams Committee, which conducted an analogous official study of pornography in England, described the danger of pornography in remarkably similar terms:

Pornography crosses the line between private and public since it makes available in the form, for instance, of a photograph, some sexual act of a private kind and makes it available for a voyeuristic interest: since it is itself a public thing, a picture book or a film show, it represents already the projection into public of the private world-private, that is to say, to its participants-of sexual activity. ${ }^{73}$

Indeed, for some the very definition of obscenity turns on the line between public and private. Harry Clor has argued that "obscenity consists in making public that which is private; it consists in an intrusion upon intimate physical processes and acts or physical-emotional states." 74 To Glor, "the essence of the obscene is its invasion of privacy. ${ }^{75}$ It might be more accurate to describe obscenity as an invasion of the public realm by "private" matters, or an "invasion of publicity," "76 because the point is to keep the public realm free of offensive sexual expression. But in any event, the sanctity of the public/private line is critical.

The centrality of the public/private line can also be seen in who is targeted for repression. The most conspicuous targets of sexual censors in recent years have not been traditional pornographers. ${ }^{77}$ Rather, they have included gays and lesbians in the military who have "come out" by expressing their sexuality; gay and lesbian artists, including Robert Mapplethorpe, ${ }^{78}$ David Wojnarowicz, ${ }^{79}$

the pervasive presence of sexually explicit materials, that challenges one of those understandings held by society for thousands of years-that sex is private.").

73 COMMITTEE ON FILM CENSORSHIP, FINAL REPORT, 1979, CMND 7772, 17.6.

${ }^{74}$ HARRY M. CloR, OBSCENITY AND PUBLIC MORALITY 225 (1969).

${ }^{75} \mathrm{Id}$.

${ }^{76} \mathrm{I}$ am indebted to Ellen Hertz for this phrase.

77 The Meese Commission found in 1986 that "[ $t$ ]he evidence is unquestionable that with few exceptions the obscenity laws that are on the books go unenforced." 1 ATTORNEY GENERAL, supra note 55, at 366.

${ }^{78}$ Robert Mapplethorpe, a gay photographer who died of AIDS in 1989, became the focus of criticism when the National Endowment for the Arts (NEA) provided some funding for a retrospective of his works that included explicit depictions of gay sex. See Michael Brenson, The Many Roles of Mapplethorpe, Acted Out in Ever-Shifting Images, N.Y. TIMES, July 22, 1989, reprinted in CULTURE WARS: DOcUMENTS FROM THE RECENT CONTROVERSIES IN THE ARTS 68 (Richard Bolton ed., 1992) [hereinafter CULTURE WARS]. In Cincinnati, local authorities went so far as to prosecute obscenity charges against the Contemporary Art Center and its director, Dennis Barrie, for 
Todd Haynes, ${ }^{80}$ Marlon Riggs, ${ }^{81}$ John Fleck, Holly Hughes, and Tim Miller; ${ }^{82}$ other artists who challenge traditional representations of sexuality, such as Karen Finley and Sally Mann; ${ }^{83}$ rap

displaying the Mapplethorpe retrospective. The jury acquitted. See Elizabeth Hess, Art on Trial: Cincinnati's Dangerous Theater of the Ridiculous, VILLAGE VOICE, Oct. 23, 1990, reprinted in CULTURE WARS, supra, at 269.

79 An essay by David Wojnarowicz, a multimedia artist who died of AIDS in 1993, was singled out by NEA Chairman John Frohnmayer as one of his grounds for revoking NEA funding from an exhibit at New York's Artists Space entitled, "Witness: Against Our Vanishing." See JOHN FrohNMAYER, LEAVING TOWN ALIVE: CONFESSIONS OF AN ARTS WARRIOR 75-81 (1993).

The American Family Association (AFA) also targeted Wojnarowicz for attack. See Wojnarowicz v. American Family Ass'n, 745 F. Supp. 130 (S.D.N.Y. 1990). It took partially cropped images (almost all representing homosexual sex) from an NEAfunded catalogue of his work, created a pamphlet that purported to represent Wojnarowicz's art work, and mailed the pamphlet to 523 members of Congress, Christian leaders throughout the country, and the press. See id. at 134. Wojnarowicz sued the AFA for misrepresenting the partial images as his artwork, and a federal district court enjoined the AFA from distributing the pamphlet, requiring it to mail a correction to everyone who had already received it. See id. at 149; see also C. CARR, Trying Times, in ON EDGE: PERFORMANCE AT THE END OF THE TwENTIETH CENTURY 260 (1993) [hereinafter ON EDGE] (discussing Wojnarowicz).

${ }^{80}$ Todd Haynes directed Poison, a feature film depicting homosexual sex, with support of the NEA. See Joyce Price, NEA-Funded Movie Repulses Conservatives, WASH. TIMES, Apr. 2, 1991, at A3; Paul Richter, The NEA Defends Funding of Controversial Film, L.A. TimES, Mar. 30, 1991, at F1.

81 Marlon Riggs directed Tongues Untied, a documentary about gay black men which appeared on public television and elicited substantial criticism. See Marc Gunther, "Tongues" Could Touch Off New Protests, ORLANDO SENTINEL, July 19, 1991, at E6; Dick Williams, PBS Fare Tonight Shatters Bounds of Taste, Morality, ATLANTA J., July 16, 1991, at A17. During the Republican presidential primaries, Pat Buchanan used a clip of Tongues Untied to attack George Bush and the NEA. See Bill Hafferty, Film Maker Reacts to Buchanan Commercial, S.F. CHRON., Feb. 28, 1992, at A8.

${ }^{82}$ Fleck, Hughes, and Miller are gay and lesbian performance artists denied NEA funding over concern that their controversial work would incur the wrath of rightwing Congressmen. See Finley v. National Endowment for the Arts, 795 F. Supp. 1457, 1461-62 (C.D. Cal. 1992). After losing a motion to dismiss and substantial discovery, the NEA agreed to settle the individual artists' claims by awarding them their grants, damages for unlawful release of information from their application files, and attorneys' fees. See Stipulation and Settlement Agreement dated June 9, 1993, Finley v. National Endowment for the Arts, 795 F. Supp. 1457 (C.D. Cal. 1992) (on file with author).

In 1992 the NEA selectively denied funding to three gay and lesbian film festivals. See Diane Haithman, Lawsuit Possible as NEA Chief Kills Grants, L.A. TIMES, Nov. 21, 1992, at F1; NEA Won't Fund 3 Gay Film Festivals, NEWSDAY (N.Y.), Nov. 21, 1992, at 8. The funding was later reinstated after a change in presidential administrations. See U.S. Arts Grants OKd for Gay Film Fests, CHI. TrIB., Aug. 26, 1993, at 16.

${ }^{83}$ Karen Finley, the fourth performance artist denied NEA funding along with Hughes, Fleck, and Miller, see supra note 82, addresses issues of women's sexuality and gay and lesbian sexuality in her work. She directly challenges contemporary culture's taboos about and objectification of women's bodies by, among other things, 
groups with explicit sexual lyrics, such as 2 Live Crew; ${ }^{84}$ AIDS educators attacked for explicit safe-sex education materials; ${ }^{85}$ and school boards challenged for introducing sex education materials that teach tolerance for gays and lesbians. ${ }^{86}$ All of these targets of repression share a refusal to abide by the lines society has drawn between private and public. ${ }^{87}$

These speakers challenge the public/private line more fundamentally than do pornographers. In a sense, pornography knows its place: it is distributed from red-light districts; it wraps its covers to shield them from public attention; and it obeys fairly stringent, if often unspoken, rules about what can and cannot be shown and where it can and cannot be shown. The community has reached something of a compromise with pornographers; pornographers can

performing in the nude in a wholly matter-of-fact way and performing a reverse striptease, starting nude and gradually dressing as the performance progresses. See CARR, Unspeakable Practices, Unnatural Acts, in ON EDGE, supra note 79, at 121; Marcelle Clements, Karen Finley's Rage, Love, Hate and Hope, N.Y. TIMES, July 22, 1990, at H5.

Sally Mann is a photographer who has been strongly condemned for taking photographs of her daughter that some see as improperly erotic. See Richard B. Woodward, The Disturbing Photography of Sally Mann, N.Y. TIMES, Sept. 27, 1992, § 6 (Magazine), at 29.

${ }^{84}$ In 1988 Alabama prosecutors charged record store owner Tommy Hammond with violating the obscenity laws by selling a 2 Live Crew record. A municipal judge found Hammond guilty, but when Hammond won the right to a new trial before a jury, he was acquitted. See MARJORIE HEINS, SEX, SIN, AND BLASPHEMY: A GUIDE TO AMERICA's CENSORSHIP WARS 77 (1993). In Florida, 2 Live Crew was also charged with obscenity for a concert performance but found not guilty. See id. at 79 .

${ }^{85}$ See Gay Men's Health Crisis v. Sullivan, 792 F. Supp. 278 (S.D.N.Y. 1992) (declaring invalid a Centers for Disease Control provision requiring federally funded AIDS education materials to be inoffensive to a majority of adults).

In 1993 four Washington, D.C., television stations refused to broadcast an advertisement by the Whitman-Walker Clinic that advocated condom use. The advertisement featured pictures of an unwrapped condom while voices recited a list of slang names for it, and concluded with the tag line: "Condom. It doesn't matter what you call it. Wear it." See Ellen Edwards, Four Local TV Stations Reject Clinic's Condom Ad, WASH. POST, Oct. 19, 1993, at C1. Condom advertisements received a similar reaction in Boston. See Dolores Kong, AIDS Condom Ads Run into Opposition, Boston Globe, Dec. 1, 1993, at 29.

${ }^{86}$ In New York City in 1993, school board elections turned into a fight over the teaching of sex education, AIDS education, and tolerance of homosexuality. See Eleanor Randolph, Schools Become Religious War Zone: New York Liberals Fight Christian Groups' Influence in Board Races, WASH. POST, May 4, 1993, at A3; see also Suzanne Fields, Fourth $R$ as in Respect, WASH. TIMES, Dec. 14, 1992, at E1 (criticizing New York materials concerning tolerance of homosexuality).

${ }^{87}$ See also Jeffrey Toobin, Annals of Law: X-Rated, NEW YORRER, Oct. 3, 1994, at 70 (detailing the targeting of gay and lesbian bookstores by Canadian officials enforcing obscenity statutes). 
and do flourish, as long as they know their proper place (the "privacy" of homes and the "red-light districts" of towns).

By contrast, the artists, educators, and gay and lesbian soldiers who have been targeted do not accept society's assigned place for their expression. The artists perform not in red-light districts but in "legitimate" public theaters such as Lincoln Center. ${ }^{88}$ Their work appears not in obscure windowless bookstores, but in distinguished public museums. ${ }^{89}$ They apply for community support through public institutions such as the National Endowment for the Arts, state arts agencies, and the Public Broadcasting System. ${ }^{90}$ By celebrating the disruptive force and shock value of sexual expression, they directly challenge the lines society has drawn between art and pornography, the sexual and the political, the private and the public. ${ }^{91}$ They demand to be treated like artists, not pornographers. ${ }^{92}$

To "come out" in any form is to challenge the public/private line of "the closet," which conditions gay and lesbian participation in the public sphere on concealing one's "private" sexual identity.

${ }^{88}$ See Clements, supra note 83, at $\mathrm{H5}$ (previewing Karen Finley's performance at Lincoln Center).

${ }^{89}$ See, e.g., Dennis Barrie, Pandering? That's Nonsense ..., N.Y. TIMES, Apr. 18, 1990, at A25 (Robert Mapplethorpe photographs in the permanent collections of the Metropolitan Museum of Art, the Art Institute of Chicago, the Victoria and Albert Museum in London, and the Centre National d'Art Georges Pompidou in Paris); Holland Cotter, At the Whitney, Provocation and Theory Meet Head-On, N.Y. TMMES, Aug. 13, 1993, at C23 (Andres Serrano photograph at the Whitney Museum of American Art); Charles Hagen, Discovering a Range of Motion in the Still Image, N.Y. TIMES, Aug. 20, 1993, at C29 (David Wojnarowicz photographs at the Museum of Modern Art).

${ }^{90}$ See, e.g., Finley v. National Endowment for the Arts, 795 F. Supp. 1457 (C.D. Cal. 1992).

${ }^{91}$ See CARR, Introduction to ON EDGE, supra note 79, at xiii, xvii-iii (describing "transgressive women performers who worked straight from the id to address issues of power and control, who made themselves monstrous on stage, acting out every definition of 'filthy' and 'mad'); LYNDA NEAD, THE FEMALE NUDE: ART, OBSCENITY AND SEXUALITY 64-70 (1992) (describing feminist performance artists' use of the body to challenge and subvert patriarchal conceptions of the representation of women). As one critic described, Karen Finley

employs an archaic art form. She takes off her clothes. . . . Finley, however, was not out to titillate or even to tingle spines. ...

... [She] transformed her naked body into a vehicle for her outrage at society's failure to stop sexism, racism, homophobia and the hundreds of other deep-seated hatreds that she sees eroding America.

Richard Huntington, A Brush With Fine Painting, BuFFalo NEws, Dec. 27, 1992, at E1, E3.

${ }^{92}$ Indeed, this may be their greatest sin, given the sharp lines society draws between art and obscenity. See infra part III.D. 
The gay and lesbian community's refusal to accept the terms of the closet has sparked a backlash of repression. Right-wing organizations like the American Family Association have attacked the NEA for funding openly gay and lesbian artists. ${ }^{93}$ President Clinton's half-hearted attempt to end the ban on gays in the military was handily defeated. ${ }^{94}$ Colorado passed an anti-gay ordinance, ${ }^{95}$ and in Oregon a similar statewide law was only narrowly defeated. ${ }^{96}$ Anti-gay violence, targeted against those who reveal their homosexuality in public, has increased. ${ }^{97}$ And gays and lesbians continue to be denied the opportunity to express their emotional commitments in public ways historically granted to heterosexuals, such as marriage..$^{98}$

The ongoing controversy over the right of gays and lesbians to serve in the military reveals the threat that sexual expression poses to the public/private line. Gays and lesbians assert their right to be open participants in one of society's most esteemed "public" institutions. ${ }^{99}$ Gays and lesbians have of course always served in the

${ }^{93}$ See, e.g., American Family Association, Is This How You Want Your Tax Dollars Spent?, advertisement in WASH. TIMES, Feb. 13, 1990, reprinted in CULTURE WARS, supra note 78, at 150; Bruce Selcraig, Reverend Wildmon's War on the Arts, N.Y. TIMES, Sept. 2, 1990, \& 6 (Magazine), at 22.

It See Chandler Burr, Friendly Fire: How Politics Shaped Policy on Gays in the Military, CAL. LAW., June 1994, at 54.

${ }^{95}$ See Evans v. Romer, 854 P.2d 1270 (Colo. 1993) (enjoining the Attorney General of Colorado from enforcing an anti-gay amendment to the Colorado Constitution).

${ }^{96}$ See George de Lama, States Take Pulse on Morality, CHI. TRIB., Nov. 5, 1992, at 18.

${ }^{97}$ See Rose Marie Arce, Anti-Gay Violence Up, NewSDAY (N.Y.), June 29, 1992, at 61; Marty Graham, Living in Fear: Hate Crimes Against Gays on Rise; Bigotry Fuels Rising Tide of Mayhem, HouSTON POST, Aug. 21, 1994, at A46. But cf. Survey Shows Decline in Anti-Gay Incidents, WASH. POST, Mar. 9, 1994 at A2 (reporting a one-year decrease in anti-gay violence after five years of steady increases).

${ }^{93}$ See William N. Eskridge, Jr., A History of Same-Sex Marriage, 79 VA. L. REv. 1419, 1421 (1993) (noting that no state has recognized gay or lesbian marriage).

${ }^{99}$ See, e.g., Pruitt v. Cheney, 963 F.2d 1160 (9th Cir. 1991), cert. denied, 113 S. Ct. 655 (1992) (challenging discriminatory treatment against military personnel on the basis of their homosexuality); Ben-Shalom v. Marsh, 881 F.2d 454 (7th Cir. 1989) (same), cert. denied, 494 U.S. 1004 (1990); Woodward v. United States, 871 F.2d 1068 (Fed. Cir. 1989) (same), cert. denied, 494 U.S. 1003 (1990); Watkins v. U.S. Army, 847 F.2d 1329 (9th Cir. 1988) (same), vacated and affd on other grounds, 875 F.2d 699 (9th Cir. 1989) (en banc), cert. denied, 498 U.S. 957 (1990); Dronenburg v. Zech, 746 F.2d 1579 (D.C. Cir. 1984) (same); Meinhold v. U.S. Dep't of Defense, 808 F. Supp. 1455 (C.D. Cal. 1993), aff'd in part and rev'd and vacated in part, Nos. 93-55242, 93-56354, 1994 WL 467311 (9th Cir. Aug. 31, 1994) (same). See generally RANDY SHIITS, CONDUCT UNBECOMING (1993) (detailing numerous examples of harassment of homosexuals in the military). 
military, but only by concealing their sexual identities. ${ }^{100}$ The military has tolerated their presence as long as they remained in the closet, as the following exchange between Congressman Barney Frank and General Colin Powell demonstrates:

Cong. Barney Frank: For some time, as you know, the Secretary [of Defense] has acknowledged, there have been gay men and lesbians in the military. Is there any evidence of behavior problems?

General Colin Powell: No, because as a matter of fact they have kept, so-called, in the closet. It is quite a different thing when it is openly practiced or openly known throughout the force and within the units. I think it makes very difficult management problems. $^{101}$

Under the military's current “don't ask, don't tell” policy applicants or soldiers are not asked whether they are gay, but if a soldier expresses in any public way that he is gay, he will be presumptively dischargeable unless he can prove that he is not. ${ }^{102}$ Thus, the military's policy is directed not at homosexuality itself, but at the expression of homosexuality to others. ${ }^{103}$

The AIDS crisis has provided still another focal point for battles over public sexual expression. Groups such as Gay Men's Health Crisis (GMHC) and ACT-UP have sought to bring to public consciousness a problem that necessitates open public discussion about heretofore private matters-namely, how and with whom one has sexual relations. ACT-UP both constitutes a political response to the AIDS crisis and demands a political response to the crisis from government. ${ }^{104}$ GMHC engages in public education about

${ }^{100}$ See generally SHILTS, supra note 99.

${ }^{101}$ Fiscal Year 1993 Defense Budget: Hearing Before the House Comm. on the Budget, 102d Cong., 2d Sess. 45 (1992).

${ }^{102}$ See National Defense Authorization Act for Fiscal Year 1994, 10 U.S.C. § 654 (1993). By contrast, an assertion that one is heterosexual does not create any presumption that one has engaged in prohibited heterosexual conduct (sodomy), despite statistics suggesting that the vast majority of heterosexuals have engaged in oral or anal sex. See LAUMANN, supra note 68 , at $98-99$ (finding that $76.6 \%$ of men and $67.7 \%$ of women admitted to having engaged in active oral sex, $78.7 \%$ of men and $73.1 \%$ of women admitted to engaging in passive oral sex, and $25.6 \%$ of men and $20.4 \%$ of women admitted to engaging in anal sex).

${ }^{103}$ See generally David Cole \& William N. Eskridge, Jr., From Hand-Holding to Sodomy: First Amendment Protection of Homosexual (Expressive) Conduct, 29 HARV. C.R.C.L. L. REV. 319 (1994) (arguing that the military policy's focus on the public expression of homosexuality violates the First Amendment).

${ }^{104}$ See Frederic M. Biddle, ACT UP's Last Act?, Boston Globe, Sept. 5, 1993 (Magazine), at 13 (describing ACT UP's tactics designed to increase governmental 
safe sex and seeks government support for its efforts. ${ }^{105}$ The threat of AIDS means that relegating sex to the private sphere may have lethal consequences. Yet the public dissemination of safe-sex educational materials remains controversial. ${ }^{106}$

These disparate controversies all illustrate the extent to which society is threatened by sex as a public subject. As Justice Stevens explained in FCC v. Pacifica Foundation: "Our society has a tradition of performing certain bodily functions in private, and of severely limiting the public exposure or discussion of such matters. Verbal or physical acts exposing those intimacies are offensive $\ldots . .107$ For the most part, social regulation is directed not at sex itself, but at its public representation, whether in pornography, art addressing sexual issues, sex education, or gays and lesbians "coming out." Time and time again, the censor's targets are those who refuse to accept the public/private line.

awareness of AIDS and to spur progress in AIDS research).

${ }^{105}$ See Gay Men's Health Crisis v. Sullivan, 792 F. Supp. 278 (S.D.N.Y. 1992) [hereinafter GMHC II] (challenging grant restrictions on AIDS education); Gay Men's Health Crisis v. Sullivan, 733 F. Supp. 619 (S.D.N.Y. 1989) [hereinafter GMHC I] (same).

${ }^{106}$ In 1987, for example, Senator Jesse Helms, reacting to explicit safe-sex educational materials created by GMHC (without federal funds), sponsored an amendment that provided that no federally funded AIDS education materials could "promote or encourage, directly, or indirectly, homosexual sexual activity." More Gay Bashing, NATION, Oct. 31, 1987, at 473 (quoting the Helms Amendment). Since a central purpose of AIDS education is to encourage "safe" sexual activity, and since the gay community was especially at risk, AIDS educators viewed this provision as undermining the purpose of AIDS education. Yet the amendment passed the Senate 94-2. See Limit Voted on AIDS Funds, N.Y. TIMEs, Oct. 15, 1987, at B12.

After a barrage of criticism, Congress amended the Helms Amendment the following year. Even this subsequent amendment, however, demonstrated ambivalence on the subject of public support for safe-sex education. Congress removed "indirectly" from the prohibition, but added a prohibition on materials that encouraged heterosexual, as well as homosexual, sexual activity. See GMHC I, 733 F. Supp. at 626. The provision now mandated that federally funded materials "not be designed to promote or encourage, directly, intravenous drug abuse or sexual activity, homosexual or heterosexual." GMHC II, 792 F. Supp. at 284 n.12. On the face of it, Congress had transformed an anti-gay law into an anti-sex law. Only under the cover of that amendment was Congress able to enact language assuring that this prohibition would not bar the creation and distribution of material educating persons in the techniques of safe sex. See id. at 288 (quoting 42 U.S.C. $\$ 300 \mathrm{ee}(\mathrm{d})$ (1988)). Thus, while the AIDS crisis has forced sexual expression into the public sphere and has led to public sponsorship of explicit sexual speech, the transformation has been exceedingly difficult, reflecting continuing social concerns about transgressing the public/private line. See generally RANDY SHILTS, AND THE BAND PLAYED ON 148-60 (1987) (describing initial official reluctance to address AIDS as a problem).

${ }^{107}$ FCG v. Pacifica Found., 438 U.S. 726, 746 n.23 (1978). 


\section{B. First Amendment Doctrine and the Public/Private Line}

The Court's sexual expression decisions can be organized along a similar public/private axis. The Court's zoning decisions allow communities to demand that when sexually explicit speech appears in public, it must be relegated to dark and distant parts of town. ${ }^{108}$ The Court's affirmance of the FCC's "indecency" regulation permits the zoning of sexual speech to less "public" times of day. ${ }^{109}$ And while private possession of obscenity cannot be regulated, ${ }^{110}$ the state is free to regulate obscenity in a public place even if it is enjoyed only by consenting adults, and even where it is only being transported through public channels for private home use. ${ }^{111}$ What is immune from regulation in private becomes suppressible in public, even if the very same speakers, listeners, and speech are involved.

The centrality of the public/private line to obscenity doctrine is most vividly reflected in Paris Adult Theatre $I v$. Slaton. ${ }^{112}$ In that case, the Court reviewed an obscenity prosecution directed at an adult movie theater that exhibited films to consenting adults only. ${ }^{113}$ The theater owners argued that because no unwilling viewer would be confronted by the films, their exhibition should be treated like Mr. Stanley's ${ }^{114}$ possession of obscene materials in the privacy of his home. ${ }^{115}$ The Court "categorically" rejected that argument, holding that the state has a "long-recognized legitimate interest in regulating the use of obscene materials in local commerce and in all places of public accommodation." 116 The Court quoted Alexander Bickel's explanation of the distinction between public and private enjoyment of obscenity:

${ }^{108}$ See supra notes 36-37 and accompanying text.

${ }^{109}$ See Pacifica, 438 U.S. at 748-51 (upholding the constitutionality of an FCC prohibition on indecent radio broadcasts during times when children are likely to be exposed to them).

${ }^{110}$ See Stanley v. Georgia, 394 U.S. 557, 568 (1969).

111 See Paris Adult Theatre I v. Slaton, 413 U.S. 49, 69 (1973) (holding that obscene films may be criminally proscribed where exhibited in public, even if shown only to consenting adults); United States v. 12 200-Ft. Reels of Super 8mm. Film, 413 U.S. 123, $128-29$ (1973) (holding that Congress may prohibit the importation of obscene materials intended for private use).

112413 U.S. 49 (1973).

${ }^{113}$ See id. at 51.

${ }^{114}$ See Stanley, 394 U.S. at 558.

${ }^{115}$ See 413 U.S. at 65.

${ }^{116}$ Id. at 57 (emphasis added); see also id. at 65 (distinguishing Stanley on the ground that movie theaters are public accommodations). 
"A man may be entitled to read an obscene book in his room, or expose himself indecently there .... We should protect his privacy. But if he demands a right to obtain the books and pictures he wants in the market, and to foregather in public places-discreet, if you will, but accessible to all-with others who share his tastes, then to grant him his right is to affect the world about the rest of us, and to impinge on other privacies. Even supposing that each of us can, if he wishes, effectively avert the eye and stop the ear (which, in truth, we cannot), what is commonly read and seen and heard and done intrudes upon us all, want it or not."

Neither Bickel's quote nor the Court's opinion adequately explains why there should be a distinction between showing an obscene film in a home, into which any number of consenting others may be invited, and showing the same film in a theater open only to the same consenting adults. If "what is commonly read and seen and heard and done intrudes upon us all, want it or not," what difference does it make whether it is "commonly" seen in private homes rather than movie theaters? ${ }^{118}$ In a familiar pattern, the distinction is asserted, but left unexplained.

The policing of the public/private line also underlies the Court's holdings that while the state may not punish the possession of obscenity in the home, it may punish any attempt to get obscenity to the home. After Stanley, several lower courts struck down limits on the importation or distribution of pornography for personal use. ${ }^{119}$ They reasoned, not illogically, that if one has a constitutional right to enjoy pornography in the home, surely one must have the right to obtain pornography for private home use. ${ }^{120}$ The

${ }^{117}$ Id. at 59 (quoting Alexander Bickel, On Pormography II: Dissenting and Concurring Opinions, 22 PUB. INTEREST 25, 26 (1971)).

${ }^{118}$ As David Richards has pointed out, Bickel's argument "rests on the crude moral confusion between an obtrusive offense and the offense derived from the mere knowledge of something." David A.J. Richards, Free Speech and Obscenity Law: Toward a Moral Theory of the First Amendment, 123 U. PA. L. REV. 45, 86 (1974); see also H.L.A. HART, LAW, LIBERTY AND MORALITY 46-47 (1963) (distinguishing between offense caused by unwanted public exposure and offense caused merely by knowing that people are engaging in conduct of which one disapproves).

${ }^{119}$ See United States v. Thirty-Seven (37) Photographs, 309 F. Supp. 36, 37-38 (C.D. Cal. 1970) (striking down statute barring obscenity importation), rev'd, 402 U.S. 363, 370-71 (1971); United States v. Orito, 338 F. Supp. 308, 310-11 (E.D. Wis. 1970) (holding unconstitutional a statute that barred the private, interstate transportation of obscenity for personal use), vacated, 413 U.S. 139, 143 (1973); United States v. Lethe, 312 F. Supp. 421, 425-26 (E.D. Cal. 1970) (holding that it is unconstitutional to prosecute an individual for mailing obscene materials to individuals who request them).

${ }^{120}$ See, e.g, Orito, 338 F. Supp. at 310 (" $[\mathrm{I}] \mathrm{t}$ follows that with the right to read 
Supreme Court rejected that logic, insisting that the line Stanley drew ended at the home's threshold, and could not be extended into the public sphere of distribution and importation. ${ }^{121}$ The Court warned of the "seductive" danger of such reasoning, and insisted that a sharp line must be drawn:

The seductive plausibility of single steps in a chain of evolutionary development of a legal rule is often not perceived until a third, fourth, or fifth "logical" extension occurs.... This kind of gestative propensity calls for the "line drawing" familiar in the judicial, as in the legislative process: "thus far but not beyond." Perspectives may change, but our conclusion is that Stanley represents such a line of demarcation . ... ${ }^{122}$

Here, the Court effectively admits that there is no logical basis for barring distribution and importation of obscenity for personal use, but insists that a (one is tempted to say "prophylactic") line must be drawn at the public/private threshold to ward off the "gestative propensity" of "seductive" reasoning.

A similar reliance on the public/private distinction helps explain one of the Court's most curious obscenity decisions, Ginzburg $v$. United States. ${ }^{123}$ Ralph Ginzburg was sentenced to five years in prison for distributing three items, none of which was obscene, ${ }^{124}$ on

obscene matters comes the right to transport or to receive such material when done in a fashion that does not pander it or impose it upon unwilling adults or upon minors.").

${ }^{121}$ See United States v. Orito, 413 U.S. 139, 143 (1973) (upholding statute barring distribution of obscenity in interstate commerce, even if only for personal use); United States v. 12 200-Ft. Reels of Super 8mm. Film, 413 U.S. 123, 128 (1973) (upholding customs statute barring importation of obscenity, even if only for personal use); United States v. Reidel, 402 U.S. 351, 352 (1971) (upholding statute barring distribution of obscenity through mails, even if directed only at consenting adults); United States v. Thirty-Seven (37) Photographs, 402 U.S. 363, 376 (1971) (plurality upholding customs statute prohibiting importation of obscenity, including obscenity imported for personal use).

${ }^{122} 12200 \mathrm{Ft}$. Reels, 413 U.S. at 127.

123383 U.S. 463 (1966).

${ }^{124}$ The first item was EROS, a book of articles and photo-essays on the subject of love, sex, and sexual relations. See $i d$. at 466 . Of the book's 15 articles and essays, the district court found that only four were obscene. See id. at 471 . The second item was Liaison, a newsletter that included an interview with a psychotherapist who favored broad license in sexual relationships, and digests of two articles from professional sex journals. See id. at 466-67. The third item was The Housewife's Handbook on Selective Promiscuity, an autobiographical account that addressed such issues as sex education for children, the legitimacy of laws regulating private consensual adult sex, and the equality of women in sexual relationships. See id. at 466-67. The Supreme Court assumed that the publications standing alone were not obscene. See id. at $465-66$. 
the ground that he engaged in "pandering" by (truthfully) emphasizing their sexual character in advertising them to the public. Had Ginzburg distributed the items only through professional psychotherapists for use in sex therapy, his actions would have been constitutionally protected. His error was to distribute these private materials in the public, commercial marketplace. Just as the same film is protected if viewed in the privacy of one's home but not if shown in a public theater, so the same materials are protected if distributed in a controlled, private therapeutic setting, but not if introduced candidly as sexual into the public marketplace.

\section{Barnes v. Glen Theatre, Inc.: Drawing Fine Lines}

The most recent example of the Court's sanctioning of public/ private policing is Barnes $v$. Glen Theatre, Inc. ${ }^{125}$ in which the Court upheld an Indiana "public nudity" statute that required nude dancers to wear pasties and a G-string. This case is about nothing but the public/private line; as Justice Scalia noted, "Indiana bans nudity in public places, but not within the privacy of the home."126 The Court's judgment in Barnes rested tenuously on three separate opinions-Chief Justice Rehnquist's plurality opinion, joined only by Justices Kennedy and O'Connor, and two separate concurrences by Justices Scalia and Souter. Virtually the only point of agreement between the five Justices who made up the majority was that Indiana's law was unrelated to the suppression of expression. ${ }^{127}$ Reaching this conclusion was necessary to uphold the statute because the Court had previously recognized nude dancing as expressive conduct, ${ }^{128}$ and had recently reaffirmed that where regulation of expressive conduct is related to its communicative aspects, it violates the First Amendment absent a compelling state interest. ${ }^{129}$ But the conclusion is highly dubious.

125501 U.S. 560 (1991).

${ }^{126}$ Id. at $576 \mathrm{n} .3$ (Scalia, J., concurring).

${ }^{127}$ See id. at 568 (plurality opinion); id. at 576 (Scalia, J., concurring); id. at 585-86 (Souter, J., concurring).

${ }^{128}$ See Schad v. Borough of Mount Ephraim, 452 U.S. 61, 66 (1981) ("[N]ude dancing is not without its First Amendment protections from official regulation."); Doran v. Salem Inn, Inc., 422 U.S. 922, 932 (1975) (stating that nude dancing involves "the barest minimum of protected expression," but is "entitled to First and Fourteenth Amendment protection under some circumstances"); California v. LaRue, 409 U.S. 109,118 (1972) (same).

${ }^{129}$ See R.A.V. v. City of St. Paul, 112 S. Ct. 2538 (1992) (applying strict scrutiny to Minnesota law prohibiting the display of racist symbols because law was designed to suppress what symbols communicated); United States v. Eichman, 496 U.S. 310, 
Rehnquist and Scalia reasoned that the state's interest in regulating public nudity was unrelated to expression because the state sought to protect "societal order and morality." ${ }^{\text {"130 }}$ Neither Justice explained, however, how public nudity harms public morality other than by virtue of what it expresses. Scalia insisted that the ban was unrelated to expression because it "generally" prohibited public nudity, irrespective of its message. ${ }^{131}$ But Scalia's use of "generally" is question-begging. The Indiana law does not "generally" prohibit all nudity, but singles out public nudity, that is, nudity communicated to others in public.

Ordinarily, where government selectively regulates public but not private conduct or expression, there is reason to suspect that the government is attempting to suppress the message communicated to the public, and strict scrutiny is triggered. In Texas $v$. Johnson, ${ }^{132}$ for example, the fact that the Texas statute prohibited only those flag burnings that would "seriously offend one or more persons likely to observe or discover ${ }^{133}$ the conduct led the Court to conclude that the government's regulatory interest was related to the message that the conduct expressed, and therefore to apply stringent First Amendment scrutiny. ${ }^{134}$ By contrast, in United States $v$. O'Brien, ${ }^{135}$ the Court justified application of relaxed scrutiny to a statute prohibiting destruction of draft cards by noting that the law "does not distinguish between public and private destruction, and it does not punish only destruction engaged in for

317-18 (1990) (applying strict scrutiny to statute criminalizing flag burning because law was designed to suppress what flag burning communicated); Texas v. Johnson, 491 U.S. 397, 407-10 (1989) (same).

${ }_{130}$ Barnes, 501 U.S. at 568; see also id. ("Public indecency statutes . . . reflect moral disapproval of people appearing in the nude among strangers in public places."); $i d$. at 575 (Scalia, J., concurring) (noting that the law's purpose was "to enforce the traditional moral belief that people should not expose their private parts indiscriminately").

${ }^{131}$ Id. at 575 n.3.

132491 U.S. 397 (1989).

${ }^{133}$ Id. at 400 n.1; see also LAURENCE H. TRIBE, AMERICAN CONSTITUTIONAL LAW 801-02 (2d ed. 1988) (arguing that the flag as a "national symbol" would not be "corrupted" in any way by "closet" burnings, but that "the symbol is degraded, if at all, only to the degree that people learn of the act"); John H. Ely, Flag Desecration: A Case Study in the Roles of Categorization and Balancing in First Amendment Analysis, 88 HARV. L. REV. 1482, 1496-1502 (1975) (arguing that regulation of public flag desecration turns on the message it communicates to others and therefore violates the First Amendment); Melville E. Nimmer, The Meaning of Symbolic Speech Under the First Amendment, 21 UCLA L. REv. 29, 53-57 (1973) (same).

${ }^{194}$ See Johnson, 491 U.S. at 405-06.

135391 U.S. 367 (1968). 
the purpose of expressing views." ${ }^{136}$ Like the flag burning statute in Johnson and unlike the draft card law in O'Brien, Indiana banned only public nudity, and did not attempt a general regulation of nudity. ${ }^{137}$

Chief Justice Rehnquist justified his conclusion that the suppression of expression was not intended by claiming that "[p]ublic nudity is the evil the state seeks to prevent, whether or not it is combined with expressive activity." 138 But public nudity has no effect on public morals except by virtue of what it expresses to

136 Id. at 375.

${ }^{137}$ Justice Scalia's suggestion that flag burning is different from public nudity because the former is "inherently expressive" misses the mark. Bames, 501 U.S. at 577 n.4 (Scalia, J., concurring). He suggests that

[i]t is easy to conclude that conduct has been forbidden because of its communicative attributes when the conduct in question is what the Court has called "inherently expressive," ... [that is,] conduct that is normally engaged in for the purpose of communicating an idea, or perhaps an emotion, to someone else.

Id. Nudity, he claims, "is not normally engaged in for the purpose of communicating an idea or an emotion." Id.

There are two flaws with this argument. First, even accepting what Scalia states, his inquiry ends too soon. If government restricts certain conduct because of what it expresses, it should not matter whether the conduct is "normally" engaged in for expressive purposes.

Second, Indiana has not prohibited nudity, but public nudity. And public nudity may well be "inherently expressive." Certainly we all understand our daily decisions about what to wear as expressive: we wear tuxedos to express one thing, judicial robes to express something else, and hot-pink jumpsuits to express something else again. In fact, the entire fashion industry is predicated on the notion that we express ourselves (and our culture) through what we wear. Moreover, what we do not wear may be at least as expressive as what we do wear: recall Brooke Shields's advertisement for Calvin Klein jeans, in which she stated, "Nothing comes between me and my Calvins." If a decision to wear lingerie as outerwear is expressive, see Phyllis C. Lowe, Bras: More Than Just Supporting Roles, L.A. TIMES (ORANCE COUNTY EDrTION), Sept. 18,1992 , at E3 (celebrating the evolution of the bra from hidden support device to "outwear essential"); Peter Mikelbank, Haute Gauche: The Trash Master, WASH. POST, July 17, 1993, at F1, F5 (discussing the recent popularity of "trash" fashion-a movement among designers to convey "sex, silliness and bad taste" through their clothes), so too is a decision to wear nothing, see Patricia McLaughlin, Can We Change Our Outlook About the Nature of Breasts?, MINNEAPOLIS STAR TRIB., Aug. 23, 1993, at IE (recognizing public toplessness as a political statement about the need to de-eroticize breasts in order to address unhealthy fetishization of the female body); Carlin Meyer, Women's Breasts: So What?, N.Y. TIMES, July 29, 1992, at A21 (arguing that laws prohibiting women from baring their breasts in public are enactments of a thinly veiled puritan morality that perpetuates deviant sexual behavior and unhealthy notions about the female body instead of curbing them). Indeed, in a society where the norm is to cover oneself up, it would be almost impossible to appear nude in public without intending to express something by one's actions.

${ }^{138}$ Barnes, 501 U.S. at 571. 
those who see it: offensiveness, immodesty, sensuality, disrespect for social mores, etc. If public nudity expressed nothing, society would have no interest in suppressing it. It is only because public nudity is expressive that it is regulated.

Justice Souter's rationale for finding the Indiana law "unrelated to the suppression of expression ${ }^{139}$ is no less strained. He reasoned that because Indiana might have determined that forbidding nude barroom dancing would further its "interest in preventing prostitution, sexual assault, and associated crimes, 140 the public nudity law should be viewed as directed at those secondary effects, and not at nude dancing's expressive elements. ${ }^{141}$ In order to reach this result, Souter had to clear several hurdles.

First, there was no indication that Indiana actually sought to further these interests. Second, there was no basis for believing that the secondary effects Justice Souter identified as flowing from nude dancers would be mitigated by pasties and a G-string. If bars featuring nude dancing attract "prostitution, sexual assault, and associated crime," it is difficult to see why bars featuring nude dancing under a pasties-and-G-string regime would not. Third, the public nudity law on its face extended beyond nude barroom dancing, reaching instances of public nudity-such as skinny-dipping, nude sumbathing, and "streaking"-with no connection to the secondary effects Souter posited as the law's justification. Although Scalia and Rehnquist relied on what they viewed as the law's "general" scope to support their determination that the statute was not targeted at suppressing the erotic messages of nude dancers, Souter relied on the law's specific application to nude barroom dancers to uphold it as a regulation directed at the secondary effects of nude dancing. ${ }^{142}$ In essence, the Justices upheld different laws. The nude dancing law Souter upheld would fail under Rehnquist

${ }^{139}$ Id. at 585 (Souter, J., concurring) (quoting United States v. O'Brien, 391 U.S. 367,377 (1968)).

${ }^{140} \mathrm{Id}$. at 584 .

141 See id. at 586.

142 Justice Souter maintained that he could ignore the broad facial scope of the law "[b]ecause there is no overbreadth challenge before us," id. at $585 \mathrm{n.2}$, but that rationale does not withstand scrutiny. The critical question is whether the state's interest in enacting the public nudity ordinance is "related to the suppression of expression." Id. at 585. Where the law on its face extends far beyond the asserted "nonexpressive" secondary effects posited, that fact suggests that the law is not in fact directed at the secondary effects, but at the communicative impact of public nudity per se. See id. at 586. 
and Scalia's analysis, which was predicated on the law generally banning all public nudity. And the law that Rehnquist and Scalia upheld would have failed Justice Souter's test, because Indiana could not possibly demonstrate secondary effects with respect to all public nudity.

Finally, and most problematically, even if nude barroom dancing has the effects Souter identified, those effects are not "secondary," but are directly linked to its communicative content. Where government regulates speech because its content is said to cause harmful effects, the government must satisfy the Brandenburg $v$. Ohio test; ${ }^{143}$ here, Indiana would have had to show that nude dancing was directed to causing unlawful conduct, and was likely to produce that effect imminently. ${ }^{144}$ In response to this concern, Souter opined that the effects might not have been caused by, but only correlated with, the nude dancing, thereby obviating the need to apply Brandenburg:

It is possible, for example, that the higher incidence of prostitution and sexual assault in the vicinity of adult entertainment locations results from the concentration of crowds of men predisposed to such activities, or from the simple viewing of nude bodies regardless of whether those bodies are engaged in expression or not. In neither case would the chain of causation run through the persuasive effect of the expressive component of nude dancing. ${ }^{145}$

Putting aside the wisdom of grounding First Amendment protection on an evanescent distinction between effects caused by or correlated with speech, each of the possibilities Souter identified is inextricably tied to nude dancing's expressive character. If "the simple viewing of nude bodies" has any effect, it must be by virtue of what the nude bodies communicate visually. Similarly, if nude dancing attracts a crowd of predisposed men, it must be because they are drawn to what nude dancing communicates to them, unless one believes that nude dancers have some magnetic force of

143395 U.S. 444, 447 (1969) (holding that the First Amendment prohibits the regulation of advocacy of illegal conduct except where speech is intended and likely to produce imminent unlawful behavior).

${ }_{144}$ See, e.g., American Booksellers Ass'n v. Hudnut, 771 F.2d 323, 333 (7th Cir. 1985), affd, 475 U.S. 1001 (1986) (striking down an antipornography ordinance justified by the concern that pornography causes violence toward women on the ground that the state had not shown a sufficiently close connection between the expression and the violence to satisfy the Brandenburg test).

${ }^{145}$ Barmes, 501 U.S. at 586. 
attraction irrespective of what they communicate. What is going on may not be "persuasive" in the strictly rational sense, but the First Amendment is not restricted to protecting rational persuasion. ${ }^{146}$

Thus, all of the Justices in the Barnes majority strained mightily to reach the conclusion that the regulation at issue was unrelated to the suppression of expression. In an exchange with the Barnes dissenters, Justice Scalia provides a clue as to why the Justices were driven to such great lengths. The dissent had argued that the Indiana law was unconstitutional, at least as applied to nude barroom dancing, because such an application had nothing to do with avoiding offense to nonconsenting parties, and therefore "the only remaining purpose must relate to the communicative elements of the performance." 147 Scalia responded:

Perhaps the dissenters believe that "offense to others" ought to be the only reason for restricting nudity in public places generally, but there is no basis for thinking that our society has ever shared that Thoreauvian "you-may-do-what-you-like-so-long-as-it-does-notinjure-someone-else" beau ideal-much less for thinking that it was written into the Constitution. ${ }^{148}$

Invoking the remarkable image of " 60,000 fully consenting adults crowded into the Hoosier Dome to display their genitals to one another," Scalia maintained that such an event could be prohibited "even if there were not an offended innocent in the crowd." 149 He argued that "[o]ur society prohibits, and all human societies have prohibited, certain activities not because they harm others but because they are considered, in the traditional phrase, 'contra bonos mores,' i.e., immoral," and one of those activities is public exposure of one's private parts. ${ }^{150}$

Thus, Scalia not only accepts the public/private line, he makes it a moral imperative. But one might as easily say flag burning, criticizing one's elected leaders, and blasphemy are "immoral." The First Amendment usually demands more than a Latin phrase to

${ }^{146}$ See Texas v. Johnson, 491 U.S. 397 (1989); Cohen v. California, 403 U.S. 15 (1971); supra part I.B.

${ }^{147}$ Barnes, 501 U.S. at 574 (Scalia, J., concurring) (characterizing dissent's position). In fact, the dissent conceded too much: even where offense to others is a rationale for regulation, such a regulation is related to the suppression of expression where the offense is generated by what is communicated. See Johnson, 491 U.S. at 414.

${ }^{148}$ Barnes, 501 U.S. at 574-75.

${ }^{149} \mathrm{Id}$. at 575.

${ }^{150} \mathrm{Id}$. 
justify the regulation of expression and specifically bars regulation based solely on a judgment that the expression is immoral. ${ }^{151}$ Thus, the majority was driven to find the Indiana statute "unrelated to expression" because it otherwise could not have upheld the law as a regulation of morals. ${ }^{152}$

Left unstated is how requiring otherwise nude dancers to don pasties and G-strings will uphold the morals of the community. The moral difference between an entirely nude dancer and a dancer wearing pasties and a G-string is not immediately apparent. But the pasties and G-string do serve an important symbolic function: they insist that the law is present in this public space, very literally enforcing a line, albeit a very fine one. The thinness of the line is ultimately less important than the fact that the line exists. The statute regulates the public sphere precisely by demanding that dancers keep their "private parts" private, but only in the most minimal sense. Thus, the pasties and G-string are an apt metaphor for the regulation of sexual expression: they symbolically police the public sphere by barring certain "private" topics from surfacing, even as they permit (and possibly even increase the desirability of) regulated sexual expression in the public sphere. They reflect

${ }^{151}$ See Kingsley Int'l Pictures Corp. v. Regents of the Univ. of N.Y., 360 U.S. 684, 687 (1959) (holding that the state may not bar exhibition of the film Lady Chatterley's Lover on the ground that it "portrays acts of sexual immorality . . . as desirable, acceptable or proper patterns of behavior" (quoting Kingsley Int'l Pictures Corp. v. Regents of the Univ. of N.Y., 157 N.E.2d 197, 197 (N.Y. 1958))); see also Cohen v. California, 403 U.S. 15, 22-23 (1971) (invalidating state regulation of public profanity that was justified on moral grounds).

${ }^{152}$ Similarly, none of the majority opinions in Barnes would stand up had the Justices not relied on an implicit distinction between sexual and political expression. Souter was most forthright about relying on this distinction, twice noting that his "secondary effects" analysis is applicable "at least in the context of sexually explicit expression" because such expression "may be of lesser societal importance." Barmes, 501 U.S. at 586 \& n.3 (Souter, J., concurring). The Supreme Court has in fact never relied on the "secondary effects" rationale to uphold the regulation of nonsexual speech, and it seems likely that if a town said it had banned a communist bookstore because it attracted unsavory characters, reduced property values, and was vaguely correlated to an increased risk of property crimes, the Court would not uphold such a ban as a content-neutral regulation of "secondary effects." Rehnquist's and Scalia's opinions would be equally implausible as applied to conventionally "political" expressive activity. Had Indiana sought to bar its citizens from wearing political symbols or clothing in public, $c f$. Tinker v. Des Moines Indep. Community Sch. Dist., 393 U.S. 503 (1969) (invalidating school regulation barring wearing of black armbands), on the ground that such conduct undermined "morals and public order," Barnes, 501 U.S. at 569, it is unlikely that the Court would have found Indiana's law "unrelated to the suppression of expression." Texas v. Johnson, 491 U.S. 397, 407 (1989). 
society's compromise on sexual expression: such expression may remain relatively free in the private sphere, but its public expression, although far from forbidden altogether, must be subject to legal regulation. ${ }^{153}$ The Court has in turn sanctioned that compromise, but in order to do so it has had to invert the First Amendment.

\section{Inverting the First Amendment}

As we have seen, the Court's principal justification for permitting the regulation of sexual expression in the public sphere is that it is not political speech. ${ }^{154}$ That justification is nothing more than a restatement of the public/private line; it maintains that sexual speech is neither a matter for public debate, nor an "essential part of any exposition of ideas." 155 But the laws upheld under this rationale are themselves designed to keep sexual expression out of the public sphere. Thus, the Court justifies the state's power to keep sexual expression "private" by relying on the nonpublic "nature" of sexual expression. Sexual expression's "private" character, however, is neither natural nor inevitable, but socially determined and reinforced by the very regulations that the Court reviews. ${ }^{156}$ The Court's rationale for allowing the regulation of

${ }^{153}$ Great Britain drove a similar "bargain" in the aftermath of the 1957 Wolfenden Report, which advocated decriminalization of private consensual sex between adults, but acknowledged the legitimacy of penalties for public displays of sexuality. See JefFrey WeEks, Sex, Politics and Society: The Regulation Of SeXuality Since 1800 , at 243 (1981) (discussing the harsher penalties for public sexual behavior and decriminalization of private acts that resulted from the Wolfenden Report); see also SIMON WATNEY, POLICING DESIRE: PORNOGRAPHY, AIDS, AND THE MEDIA 60-61 (2d ed. 1989) (arguing that the Wolfenden Report led to obsessive policing of "public" places in exchange for private freedom).

${ }^{154}$ See supra part I.A.

${ }^{155}$ Paris Adult Theatre I v. Slaton, 413 U.S. 49, 61 n.12 (1973) (quoting Chaplinsky v. New Hampshire, 315 U.S. 568, 572 (1942)).

${ }^{156}$ Both conservative and liberal critics recognize that the delineations we construct between public and private spheres are chosen, not natural, and that these choices bear significant social consequences. See, e.g., CLOR, supra note 74, at 200 (arguing that the public/private distinction collapses because civil society has a stake in encouraging and discouraging private sexual activity); LORD PATRICK DEVLIN, THE ENFORCEMENT OF MORALS 7-25 (1965) (rejecting claim that there is a private realm of sexuality immune from government control); Ruth Colker, Pomography and Privacy: Towards the Development of a Group Based Theory for Sex Based Intrusions of Privacy, 1 LAW \& INEQ. J. 191, 198-213 (1983) (advancing a feminist critique of the public/ private distinction); Alan Freeman \& Elizabeth Mensch, The Public-Private Distinction in American Law and Life, 36 BuFF. L. REV. 237, 238 (1987) (emphasizing that the public/private distinction is socially constructed); Catharine A. MacKinnon, Feminism, 
public sexual expression is therefore circular.

The Court's justification for protecting sexual expression in the private sphere is equally problematic. Here, the First Amendment prohibits the state from intruding upon expressive interests because (and only so long as) they are privately expressed. ${ }^{157}$ But proponents of regulation maintain that private sexual expression has a distinctly public effect. Conservatives identify its detrimental influence on public morality, ${ }^{158}$ while feminists point to pornography's role in enforcing women's subordinate status. ${ }^{159}$ Thus, just as the assertion that sexual speech is not political cannot in itself justify excluding sexual speech from public debate, so the assertion that sexual speech is private is insufficient to explain the Court's protection of such expression in the private sphere.

The public/private line that the Court has endorsed is not, of course, unfamiliar. In liberal society generally and American culture in particular, the "private" sphere is generally seen as relatively free from government control, while the "public" sphere is subject to regulation. ${ }^{160}$ The Court's doctrinal approach to sexual expression neatly traces that distinction. Indeed, many of those who have

Marxism, Method, and the State: Toward Feminist Jurisprudence, 8 SIGNS 635, 656-57 (1982) (discussing the social creation and implications of the public/private construct); Louis M. Seidman, Public Principle and Private Choice: The Uneasy Case for a Boundary Maintenance Theory of Constitutional Law, 96 YALE L.J. 1006, 1006 (1987) (questioning the validity of the public/private construct).

${ }^{157}$ See Stanley v. Georgia, 394 U.S. 557, 566 (1968) ("Whatever the power of the state to control public dissemination of ideas inimical to the public morality, it cannot constitutionally premise legislation on the desirability of controlling a person's private thoughts.").

${ }^{158}$ See CLOR, supra note 74, at 200-07 (contending that government cannot remain neutral toward sexual expression even in the private sphere); DEVLIN, supra note 156, at 11 (arguing that society may use law to protect public morality because such morality is essential to societal vitality); see also Louis B. Schwartz, Morals Offenses and the Model Penal Code, 63 ColuM. L. REv. 669, 671 (1963) ("[T] he great majority of people believe that the morals of 'bad' people do, at least in the long run, threaten the security of the 'good' people. Thus, they believe that it is their own business they are minding.").

${ }^{159}$ See, e.g., MACKINNON, supra note 64 , at 146-62 (examining the tangible harms caused to women by the private consumption of pornography).

${ }^{160}$ See, e.g., Ruth Gavison, Feminism and the Public/Private Distinction, 45 STAN. L. REV. 1, 6 (1992) (" $[\mathrm{A}]$ ] central sense of the public/private distinction contrasts freedom with interference. Here, the 'private' is the 'free,' the sphere in which others do not interfere."); Robert H. Mnookin, The Public/Private Dichotomy: Political Disagreement and Academic Repudiation, 130 U. PA. L. REV. 1429, 1429 (1982) (describing the private sphere as "presumptively outside the legitimate bounds of government coercion and regulation" and the public sphere as a place "where government has a legitimate role"). 
opposed the regulation of obscenity argue, on libertarian grounds inspired by John Stuart Mill, that the private consumption of pornography should not be subject to government regulation because it does not inflict tangible harm on others. ${ }^{161}$

But while the public/private line may be familiar from liberal political theory, from a First Amendment standpoint it is perverse. The First Amendment protects public values; one of its central purposes is to protect an "uninhibited, robust, and wide-open" public debate. ${ }^{162}$ While some of the values furthered by the First Amendment, such as self-realization and autonomy, ${ }^{163}$ apply in both the private and public spheres, others have a distinctly public character. Both Alexander Meiklejohn's view of the First Amendment as a guarantee of speech essential to self-government and Vincent Blasi's conception of a guarantee of speech that functions to check abuses by government officials imply increased protection for expression in the public sphere. ${ }^{164}$ So too does Lee Bollinger's vision of the First Amendment as educating the citizenry about tolerance; ${ }^{165}$ tolerance of expression that is hidden from the

${ }^{161}$ See, e.g., HART, supra note 118, at 4-6 (defending and qualifying Mill's philosophy in the context of sexual morality); Louis Henkin, Morals and the Constitution: The Sin of Obscenity, 63 CoLUM. L. REv. 391, 391 (1963) (noting that traditional libertarian thought shuns state regulation of sexual expression in the private sphere); William B. Lockhart \& Robert C. McClure, Literature, the Law of Obscenity, and the Constitution, 38 MINN. L. REv. 295, 382 (1954) (concluding that potential harms resulting from sexual expression in literature are insufficiently tangible to warrant state interference with such expression). See generally CLOR, supra note 74, at 88-135 (discussing "libertarian" objections to regulation of obscenity); Ronald Dworkin, Liberal Community, 77 CAL. L. REv. 479, 480-84, 495-97 (1989) (assessing the validity of Mill's harm principle with respect to nonphysical injury).

${ }^{162}$ New York Times Co. v. Sullivan, 376 U.S. 254, 270 (1964).

${ }^{263}$ See C. EDWIN BAKER, HUMAN LIBERTY AND FREEDOM OF SPEECH 47-51 (1989) (discussing the value of self-determination and autonomy); Martin $\mathrm{H}$. Redish, The Value of Free Speech, 130 U. PA. L. REV. 591, 593 (1982) (arguing that the First Amendment serves the value of "individual self-realization"); Thomas Scanlon, $A$ Theory of Freedom of Expression, 1 PHIL. \& PUB. AFF. 204, 215-17 (1972) (theorizing that free expression may serve to protect individual autonomy).

${ }^{164}$ See alexander Meiklejohn, Free SpeEch and Its Relation to SelfGOVERNMENT 27 (1948) ("To be afraid of ideas, any idea, is to be unfit for selfgovernment"); Vincent Blasi, The Checking Value in First Amendment Theory, 1977 AM. B. FOUND. RES. J. 521, 533; see also JOHN H. ELY, DEMOCRACY AND DISTRUST 105-34 (1980) (stating that freedom of speech is essential to keep open the channels of political change); Robert C. Post, The Constitutional Concept of Public Discourse: Outrageous Opinion, Democratic Deliberation, and Hustler Magazine v. Falwell, 103 HARV. L. REV. 601, 672 (1990) (arguing that free public discourse is essential to democratic government, and that "any effort substantively to circumscribe public discourse is necessarily self-defeating, for it displaces the very democratic processes it seeks to facilitate").

${ }^{165}$ See Lee C. Bollinger, The Tolerant Society: Freedom of Speech and 
public eye serves the First Amendment's pedagogical goals much less directly than tolerance of speech with which we are confronted in public. Because freedom of speech in the public domain is so essential to the First Amendment's core values, the Amendment's guarantees are generally stronger with respect to public than private matters. ${ }^{166}$ Accordingly, the Supreme Court has repeatedly reaffirmed the importance of protecting political speech in the public sphere. ${ }^{167}$

Public sexual expression, however, receives none of this protection: indeed, the more sexual expression seeks to enter the public arena, the more the Court sanctions its suppression. Social regulation of sexual expression is driven by a moral judgment that certain sexual expression should remain a private matter. Yet the First Amendment generally precludes the regulation of expression on any moral grounds and holds especially suspect the particular moral judgment enforced here: namely, that speech should be selectively suppressed precisely because it has been expressed in public. The moral judgment that drives the sexual speech doctrine is thus doubly antithetical to the First Amendment tradition. If the sexual expression cases can be explained, they must find their justification not in traditional First Amendment principles, but in the specific values furthered by enforcing a public/private line in matters of sexuality. When one examines the effects of enforcing that line, however, it is far from clear that the line serves the purposes that proponents of regulation claim for it.

\section{EXTREMIST SPEECH IN AMERICA 155-57 (1986).}

${ }^{166}$ See, e.g., Connick v. Myers, 461 U.S. 138, $143-49$ (1983) (holding that when a public employee speaks on matters of personal interest and not public concern, the court will not apply heightened scrutiny).

${ }^{167}$ See, e.g., id. at 145 ("[S]peech on public issues occupies the "highest rung of the heirarchy [sic] of First Amendment values' ...." (quoting NAACP v. Clairborne Hardware Co., 458 U.S. 886, 913 (1982))); Cohen v. California, 403 U.S. 15, 24 (1971) ("[Freedom of expression] is designed and intended to remove governmental restraints from the arena of public discussion ... in the hope that use of such freedom will ultimately produce a more capable citizenry and [a] more perfect polity ... upon which our political system rests."); New York Times Co. v. Sullivan, 376 U.S. 254, 270 (1964) ("TThe] debate on public issues should be uninhibited, robust, and wide open . . ." ); Thornhill v. Alabama, 310 U.S. 88, 101 (1940) ("The freedom of speech and of the press ... embraces at the least the liberty to discuss publicly and truthfully all matters of public concern ...." ). 


\section{SEX AND CivilizATION}

What drives our society (and the Supreme Court) to insist upon maintaining a public/private line with respect to sexual expression, and what purpose does such regulation serve? Several explanations have been offered, none completely satisfactory. I will review several of these explanations and ultimately suggest that the regulation of sexual expression has the paradoxical effect of enforcing (and reinforcing) a pornographic conception of sexuality. ${ }^{168}$

\section{A. Avoiding Offense to Others}

One of the most common justifications for the public/private line maintains that the line is necessary to protect children and unconsenting adults from exposure to offensive and degrading materials. ${ }^{169}$ Much like a public nuisance, sexual expression in public, whether it be nudity, sexual conduct, or depictions thereof, intrudes on the rights of those who seek to live in a community free of that type of expression. Whether or not we ultimately agree with their tactics, many would look upon community groups organizing against the opening of an X-rated bookstore in their neighborhood differently than we would look upon an effort to exclude an AfricanAmerican or Communist bookstore. ${ }^{170}$ By allowing communities

${ }^{168}$ Although I draw upon broader sources for this analysis, my observations do not purport to make universal claims for all cultures, but are limited to observations about the United States's contemporary cultural attitudes toward sexual expression.

${ }^{169}$ Many of those who argue for the protection of private sexual freedom acknowledge society's interest in regulating public sex. See, e.g., HART, supra note 118, at 4347 (arguing against the regulation of private sexual practices based on their "immorality," but conceding that public sexual practices could be regulated because of the offense they inflict on others); see also Barnes v. Glen Theatre, Inc., 501 U.S. 560, 590-91 (1991) (White, J., dissenting) (conceding legitimate government interest in protecting unwilling viewers from offense of public nudity); HERBERT L. PACKER, THE LIMITS OF THE CRIMINAL SANCTION 324 (1968) ("The only valid purpose of obscenity laws is to prevent public offense. It should be viewed, purely and simply, as the proscription of nuisance."); Henkin, supra note 161, at 401 ("It may be that the Constitution regards state concern with private morality privately indulged differently from state protection of the sensibilities of others against offensive public display ...."); Schwartz, supra note 158, at 674-75 (noting that the Model Penal Code penalizes "open lewdness" as a kind of public nuisance).

${ }^{170}$ For example, the New York Times, which generally adopts a very pro-free-speech stance, recently editorialized in favor of restrictive zoning of adult video and pornography stores in New York. See Zoning, Sex, and Videotape, N.Y. Times, Sept. 15, 1994, at A22. It is inconceivable that the Times would support restrictive zoning of offensive political bookstores. 
to zone adult businesses out of their neighborhoods, but barring outright suppression of X-rated literature, the Court allows the community to maintain a "clean environment" at the same time as it permits individuals access to sexual expression that can be enjoyed in the privacy of their homes, or at least away from the most public areas.

But this conventional rationale for the public/private distinction is open to question. Why, for example, is a bookstore selling sexually explicit books more objectionable than one selling violent, misogynistic, or politically radical books? The perception that a sexually explicit bookstore is more damaging to the quality of life and that unwanted exposure to sexual expression is categorically different from unwanted exposure to any other kind of expression that the listener deems offensive may ultimately rest on nothing more than social discomfort with and prejudice against sexual expression. If so, this rationale only adds another layer of circularity to the argument in favor of repression of public sexual expression.

I do not mean to suggest that there is no social interest in avoiding offense from public displays of sexuality. Quite plainly, our society has extremely strong norms-both formal and informal-against precisely such displays. But we also have strong norms against all manner of uncivil and dissident behavior, yet the First Amendment generally protects such behavior from legal regulation. ${ }^{171}$ Thus, it is not enough to say that public sexuality should be treated like a public nuisance; ${ }^{172}$ rather, one must explain why representations of sex in particular should be treated in that manner, but other offensive or degrading public displays-such as swastikas, flag burning, profanity, hate speech, and the like-are not.

Moreover, even if one were to accept the legitimacy of the interest in avoiding offense to unwilling viewers, that rationale does not account for the permissible scope of legal regulation. Obscenity doctrine applies even where there is no risk of offending children

171 See, e.g., R.A.V. v. City of St. Paul, 112 S. Ct. 2538 (1992) (invalidating a municipal ordinance prohibiting hate speech as impermissibly content-based); Hustler Magazine, Inc. v. Falwell, 485 U.S. 46 (1988) (shielding the publisher of an offensive parody of a public figure); Cohen v. California, 403 U.S. 15 (1971) (reversing a conviction under a state breach of peace statute for wearing a jacket bearing the message, "Fuck the Draft"); Post, supra note 164, at 606 (describing the Falwell decision as "an important articulation of the first amendment right to give offense").

${ }^{172}$ See supra note 169. 
or unconsenting adults. ${ }^{173}$ The public nudity law upheld in Barnes applied to adults-only nude dancing bars where there was no danger of offending children or unwilling viewers. ${ }^{174}$ The Court has expressly rejected arguments that sexual expression may be regulated only for the purpose of avoiding offense to others and has found a legitimate interest in prohibiting immoral sexual expression even where no listener is offended. ${ }^{175}$ Thus, the interest in avoiding offense to others fails to justify the disfavored treatment of public sexual expression on two counts. It does not meaningfully distinguish treatment of offensive sexual speech from treatment of other kinds of offensive speech. Nor can it explain the scope of sexual speech regulation condoned by the Court.

\section{B. Mediating the Universal and the Particular}

From a broader perspective, Michael Seidman has argued that the public/private distinction serves to mediate basic but conflicting human desires and needs in a liberal community. ${ }^{176}$ He identifies an inherent contradiction between the universalist ethic that we should "treat all members of an expansively bounded community with equal concern and respect," and our particularistic need to love and care for certain people-such as family and friends-above all others. ${ }^{177}$ Society demands equal respect for all, and its rules and regulations must satisfy that demand in order to be legitimate. As citizens, then, we are directed to treat all equally. At the same time, however, we find particular fulfillment in relationships that rise above equal respect for our fellow citizens-relationships characterized by love, passion, and loyalty. These feelings cannot be generalized: we cannot love everyone like we love our spouses, children, siblings, parents, and friends. Love means holding a specific individual or individuals above all others. Thus, the universalist demand of equal respect inherently contradicts the particularist demands of romantic and familial love.

${ }^{173}$ See Paris Adult Theatre I v. Slaton, 413 U.S. 49, 68-69 (1973).

174 See Barnes v. Glen Theatre, Inc., 501 U.S. 560,566 (1991).

${ }^{175}$ See id. at 575 (Scalia, J., concurring); Paris Adult Theatre I, 413 U.S. at 57-60, 65. But cf. Kingsley Int'l Pictures Corp. v. Regents of the Univ. of N.Y., 360 U.S. 684, 68889 (1959) (forbidding a state from censoring a film as obscene simply because the film expresses immoral ideas about adultery).

${ }^{176}$ See Seidman, supra note 156, at 1007. See generally PUBLIC AND PRIVATE IN Social LIFE (Stanley I. Benn \& Gerald F. Gaus eds., 1983) [hereinafter PUBLIC AND Private].

${ }^{177}$ Seidman, supra note 156 , at 1019-23. 
In Seidman's view, the public/private distinction mediates this contradiction by providing separate spheres in which we can "play out our separate and contradictory public and private lives." The private sphere allows for the pursuit of individualist or particularistic ends, whereas universalist or communitarian goals govern the public sphere.

Sexual expression is undoubtedly an important mechanism for furthering the intimate, particularistic values associated with love. If sexual expression necessarily implicates such particularist values, its exclusion from the public sphere may be required in order to avoid disruption of the universalist ethic that governs there. But it is difficult to maintain that sexual expression is necessarily particularistic, given the widespread use of sexual appeals in public culture. Sex symbols, for example, are quintessentially public and universal figures. Their appeal has everything to do with the public images of sexuality advanced by the fashion and entertainment industries and little if anything to do with the particularistic values associated with the private sphere.

Moreover, society does not demand that all representations of particularistic love be restricted to the private sphere. Romantic love is the stuff of bestselling books, movies, plays, and compact discs. Public airing of our innermost psychological and emotional selves is a staple of biography, memoirs, literature, and daytime talk shows. If these particularistic ideals can be publicly aired without undermining their character, why is the public representation of sex different?

Indeed, there can be no clean boundary between public and private sexual expression. As Seidman points out, the boundaries of the private sphere are necessarily drawn in the public realm, thereby making the identification of any private boundary line itself a public matter. ${ }^{179}$ This is especially true of sexuality, which, although often treated as "private" and "natural," is to a significant extent socially constructed: what and who we see as "sexy," what we expect from sex, and ultimately how we define our "sexuality" has as much to do with public culture as with some presocial private desire. As Michel Foucault has argued:

${ }^{178}$ Id. at 1019 . Others have similarly described the public/private distinction as a way of mediating the contradictions between individualist and communitarian values. See Stanley I. Benn \& Gerald F. Gaus, The Liberal Conception of the Public and the Private, in PUBLIC AND PRrvate, supra note 176, at 31, 31.

${ }^{179}$ See Seidman, supra note 156, at 1020-23. 
Sexuality must not be thought of as a kind of natural given which power tries to hold in check, or as an obscure domain which knowledge tries gradually to uncover. It is the name that can be given to a historical construct: not a furtive reality that is difficult to grasp, but a great surface network in which the stimulation of bodies, the intensification of pleasures, the incitement to discourse, the formation of special knowledges, the strengthening of controls and resistances, are linked to one another .... ${ }^{180}$

To the extent that sexuality is socially constructed, it is always already public.

Moreover, Seidman's conception of different spheres serving different functions does not explain a unique attribute of the identification of sex as private. To say that a matter is private ordinarily implies only that it is presumptively immune from social regulation; it does not generally follow that society may mandate that the matter remain private. We are generally permitted to reveal our private affairs in public if we so choose. Yet, in the context of sexual expression, one often finds the rhetoric of privacy used not to justify freedom from regulation, but to rationalize the forcible exclusion of sexual expression from the public sphere. Father Ritter, for example, writing in the Report of the Attorney General's Commission on Pornography, condemns pornography for its "total and inadmissible invasion of a personal privacy so sacred and so inalienable that it must always remain inviolate. ${ }^{181}$ In a remarkable non sequitur, Ritter reasons that because sexual privacy is an "inalienable" right, public sexual expression must be regulated. Seidman's notion of separate spheres may explain why a society would seek to protect private sexual expression from government

1801 MiChel FOUCAULT, THE HISTORY OF SEXUALITY: AN INTRODUCTION 105-06 (Robert Hurley trans., 1990); see also id. at 155-57 (arguing that sex has become of paramount importance in our society, to the point of creating "the desire to have it, to have access to it, to discover it, to liberate it, to articulate it in discourse [and] to formulate it in truth"); WEEKS, supra note 153, at 96-121 (discussing the construction of homosexuality); William N. Eskridge, Jr., A Social Constructionist Critique of Posner's Sex and Reason: Steps Toward a Gaylegal Agenda, 102 YALE L.J. 333, 365-66 (1992) (discussing social construction of sexuality); Eskridge, supra note 98, at 1421-22 (explaining the social construction of same-sex marriage and relationships); Milton C. Regan, Jr., Reason, Tradition and Family Law: A Comment on Social Constructionism, 79 VA. L. REV. 1515, 1521-22 (1993) (discussing socially constructed views of sexual orientation and same-sex marriages). Although there is some evidence that homosexuality and heterosexuality are in part genetically determined, see Chandler Burr, Homosexuality and Biology, ATLANTIC MONTHLY, Mar. 1993, at 47, 64-65, that evidence does not suggest that sexuality is exclusively genetically determined.

${ }^{181} 1$ ATTORNEY GENERAL, supra note 55, at 97 (statement of Father Bruce Ritter). 
regulation, but what explains the social mandate to keep sexual expression private?

\section{Freud and Foucault: The Repression Hypothesis and Beyond}

One of the now-conventional accounts for why we exclude sex from the public sphere is attributable to Sigmund Freud, who maintained that repression of the libido is essential to civilization. ${ }^{182}$ In Freudian theory, everyone's first love object is his or her opposite-sex parent, and both development of the personality and maintenance of the family require repression of these incestuous desires. ${ }^{183}$ From a societal standpoint, Freud thought the repression of sexual drives necessary to redirect human energy into more socially productive endeavors. Absent repression, the theory goes, we would be even more obsessed with sex than we already are, and no one would bother making the trains run on time. ${ }^{184}$ Freud also considered sexual repression essential to social bonding. ${ }^{185}$

${ }^{182}$ See Sigmund FREUd, CIVILIZATION AND ITS DiscontenTs 64-74 (James Strachey ed. \& trans., 1961). The view that sexual repression is necessary to maintain civilization is by no means unique to Freud. As Thomas Grey reports:

[E]very thinker of the great central tradition of the last century's social thought has seen repressed sexuality and the authoritarian family structure as close to the core of our civilization. Conservative theorists have defended repression as necessary; revolutionaries have urged that society would have to be overthrown to free us from its tyranny.

Thomas C. Grey, Eros, Civilization and the Burger Court, L. \& ConTEMP. ProbS., Summer 1980, at 83, 92; see also id. at $92-95$ (tracing the linkage of sexual repression and civilization through two strains of thought: one from Emile Durkheim to Max Weber to Joseph Schumpeter and the other from Friedrich Engels to Herbert Marcuse to Wilhelm Reich).

${ }^{183}$ See FREUD, supra note 182, at 59-60.

${ }^{184}$ See id. Harry Clor, arguing in favor of regulating obscenity, expressly relies on Freud:

Every community must devote its attention to the discipline and direction of powerful natural impulses. Every social order must endeavor to give the sensual side of life its due while preventing undue or excessive preoccupation with it. The minds and energies of citizens must be available for the long-range pursuits and higher ends of the community. This requires socially imposed restraints upon the indulgence of the passions and, also, socially imposed standards and values concerning the indulgence of the passions.

CloR, supra note 74, at 197.

${ }^{185}$ See FREUD, supra note 182, at 65; see also 18 SIGMUND FREUD, Some Neutotic Manifestations in Jealousy, Paranoia and Homosexuality, in THE COMPLETE PSYCHOLOGICAL WORKS OF SIGMUND FREUD 221, 232 (James Strachey ed. \& trans., 1955) (arguing that repression and sublimation of homosexual desire in men, attached initially to the father, is necessary to the male bonding upon which civilization is built). 
In Seidman's terms, the particularism associated with a sexual relationship (which encourages favoritism, sparks jealousy, and may lead to aggression toward others) threatens the universalist values necessary to membership in a larger community. In the military parlance, "unit cohesion" requires desexualized ties. ${ }^{186}$

The contours of the sexual speech doctrine can be seen in Freudian terms. Freud posited that repression of sexuality does not eradicate sexual thoughts, but merely submerges them into the unconscious, where they continue to affect behavior and return in the form of symptoms. ${ }^{187}$ The Court similarly permits repression but not suppression of most sexual speech. The state may limit offensive but nonobscene sexual expression to particular parts of town or particular times of day, as if to banish it to society's "unconscious," but may not suppress it altogether. ${ }^{188}$

Even in the obscenity realm, where the doctrine on its face appears to authorize outright suppression of speech, in fact only partial repression is achieved. Because of the application of local community standards, hard-core obscenity is not forbidden altogether but rather limited to distribution from the nation's redlight districts: among others, New York City's Times Square, Boston's Combat Zone, and San Francisco's Tenderloin. In New York City, for example, the Second Circuit has held that nothing

${ }^{186}$ See, e.g., Bernard E. Trainor \& Eric L. Chase, Don't Compromise the Ultimate Mission, N.J. L.J., May 17, 1993, at 17, 32 (arguing that the military's ban on homosexuals is justified to forestall sexual tension that would undermine "unit cohesion").

For similar reasons, even before the modern-day concern with sexual harassment, businesses often prohibited or discouraged sexual relationships between employees. Even where such relationships are not expressly prohibited, fellow employees will often seek to keep their relationships a secret at work. The apocryphal story of the woman who slept her way to the top reflects not only male anxiety about women in the workplace, but also the threat that sex is thought to pose to what some consider the universalist meritocracy of the public world.

${ }^{187}$ See Sigmund Freud, DORA: AN ANALYSIS OF A CASE OF Hysteria 146 (Philip Rieff ed., 1963).

${ }^{188}$ See, e.g., Sable Communications v. FCC, 492 U.S. 115, 126 (1989) (invalidating a total ban on dial-a-porn services but indicating that more limited restrictions may be permissible); City of Renton v. Playtime Theatres, Inc., 475 U.S. 41, 46-47 (1986) (permitting the zoning of adult theaters but suggesting that a total ban would be invalid); FCC v. Pacifica Found., 438 U.S. 726, 750 (1978) (permitting FCC restrictions barring sexually indecent broadcasting only during certain hours of the day); Action for Children's Television v. FCC, 932 F.2d 1504, 1508-09 (D.C. Cir. 1991) (rejecting a complete ban on broadcasting indecent speech and holding that some safe harbor for indecent material is constitutionally required), cert. denied, $112 \mathrm{~S}$. Ct. 1281 (1992). 
could be patently offensive by community standards; thus, no obscenity can be prohibited there. ${ }^{189}$ Furthermore, throughout the nation, obscenity in the home is immune from suppression. ${ }^{190}$ Thus, the Court's sexual speech doctrine functions less to permit the suppression of sexual expression than to permit its repression from the visible "public" sphere, just as, in Freud's view, the psyche banishes unwelcome sexual thoughts to the unconscious, but cannot extinguish them altogether.

More recently, Michel Foucault challenged Freud's theory of sexual repression, arguing that the "repressive hypothesis" misunderstands the mechanisms by which sex is regulated. ${ }^{191}$ In Foucault's view, modern society, far from repressing sexuality, has "compell[ed] sex to speak."192 From the confessional to the analyst's couch to the Oprah Winfrey show, Western society is preoccupied with talking about sex. Foucault maintains, however, that this apparent lifting of repression has not in fact been liberating; rather, open discussion, categorization, and classification of sex effect social control more efficiently and intricately than does blunt repression. ${ }^{193}{ }^{~}[\mathrm{~W}]$ hat is involved is the production of sexuality rather than the repression of sex. ${ }^{n 194}$ In this view, social power over individual citizens is exercised through the proliferation of discourses about sex and through a culture that treats sexuality and its investigation as the central truth about personal identity. ${ }^{195}$

The law's obsession with the public/private distinction appears to make less sense from Foucault's perspective than from Freud's. If social control is achieved more directly through public discourse

${ }^{189}$ See United States v. Various Articles of Obscene Merchandise, 709 F.2d 132, 137 (2d Cir. 1983).

${ }^{190}$ See Stanley v. Georgia, 394 U.S. 557, 565 (1969) (holding that the First Amendment prohibits criminalizing mere private possession of obscene materials).

${ }^{191}$ See FouCAULT, supra note 180 , at 10, 17-49.

192 Id. at 158.

${ }^{193}$ See id. at 23-25.

194 Id. at 114.

${ }^{195}$ See id. at 69-70. Foucault explains:

[I]t is this desirability of sex that attaches each one of us to the injunction to know it, to reveal its law and its power; it is this desirability that makes us think we are affirming the rights of our sex against all power, when in fact we are fastened to the deployment of sexuality that has lifted up from deep within us a sort of mirage in which we think we see ourselves reflected-the dark shimmer of sex.

Id. at 156-57. For Foucault, then, Western society's preoccupation with sex provides the mechanism for "power" (the source of which is generally unidentified in Foucault's work) to more closely control us. 
about sex than through the relegation of sex to the private sphere, one might expect to see less insistence on the public/private line. Indeed, it was precisely for that reason that Thomas Grey predicted in 1980 that "within a few years fornication and sodomy laws will be found unconstitutional. ${ }^{196} \mathrm{He}$ reasoned that given the increasingly public presence of the homosexual community and the sheer numbers of citizens living together (and engaging in sexual relations) outside of marriage, the law would "legitimate" those relationships in order to bring them above ground, where they would be more subject to social control.

But Grey's prediction has not yet been realized. Six years after his article was published, the Supreme Court upheld a sodomy statute in Bowers v. Hardwick. ${ }^{197}$ Sodomy statutes remain on the books in many states, and no state will legitimate gay or lesbian relationships through marriage. ${ }^{198}$ There has undoubtedly been, however, some evolution in the direction Grey foresaw. The gay and lesbian rights movement has made great strides in changing popular (and judicial) opinion in recent years, so much so that legal challenges to discriminatory policies against gays and lesbians in the military-a defendant to which the courts are usually exceedingly deferential-have succeeded in the lower courts. ${ }^{199}$ And it seems

${ }^{196}$ Grey, supra note 182, at 97. Grey argued that the Court's "privacy" decisions were predicated not on an individualist notion of the right of consenting adults to control their own sex lives, but on society's need to enforce "order and social stability." Id. Thus, he saw Griswold v. Connecticut, 381 U.S. 479 (1965), and Roe v. Wade, 410 U.S. 113 (1973), which guaranteed the rights to contraceptives and abortion, as protecting "the stability-centered concerns of moderate conservative family and population policy." Grey, supra, at 90 .

${ }^{197} 478$ U.S. 186 (1986).

${ }^{198}$ See Eskridge, supra note 98, at 1421.

${ }^{199}$ See, e.g., Steffan v. Aspin, 8 F.3d 57, 59 (D.C. Cir. 1993) (holding that Navy regulations compelling a midshipman to resign from the Naval academy solely because he was an admitted homosexual violate equal protection), vacated and reh' $g$ en banc granted, No. 91-5409, 1994 U.S. App. LEXIS 9977 (Jan. 7, 1994); Meinhold v. United States Dep't of Defense, 808 F. Supp. 1455, 1458 (C.D. Cal. 1993) (holding that a policy of banning homosexuals from military service based merely on sexual orientation violates equal protection), aff'd in part and rev'd and vacated in part, Nos. 93-55242, 93-56354, 1994 WL 467311, at *1 (9th Cir. Aug. 31, 1994) (holding that servicemen may be discharged because of homosexual acts, but not merely because of homosexuality); Dahl v. Secretary of the United States Navy, 830 F. Supp. 1319, 1335, 1337 (E.D. Cal. 1993) (same); Elzie v. Aspin, 841 F. Supp. 439, 443-44 (D.D.C. 1993) (same); Selland v. Aspin, 832 F. Supp. 12, 15 (D.D.C. 1993) (same).

A 1993 Gallup Poll shows that $80 \%$ of the public supports equal job opportunity for gays, as compared to only 59\% in 1982. See U.S. Poll Shows Division on Issue of Homosexuals, ST. LOUIS POST-DISPATCH, Apr. 30, 1993, at C1. In general, public opinion polls show that "there has been a steady erosion over the past 20 years of 
likely that Bowers will eventually be reversed; it is one of the Supreme Court's most widely criticized decisions. ${ }^{200}$

But the picture is far more complex than Grey painted it. The growing gay-rights movement has been met in turn by growing opposition from right-wing groups. ${ }^{201}$ Sodomy statutes remain on the books in eighteen states ${ }^{202}$ and anti-gay ordinances have become the next wave of legislation. ${ }^{203}$ While the sodomy laws are rarely enforced except as backstops for prosecutions of rape or prostitution, ${ }^{204}$ their existence arguably encourages less formal forms of "enforcement," including private and public discrimination against gays and lesbians, and gay-bashing. ${ }^{205}$

public support for laws and practices that discriminate against homosexuals." Richard Harwood, 'Strangers' In Our Midst, WASH. PosT, Feb. 26, 1993, at A23.

200 See Charles Fried, ORDer and LaW: ARguinc the Reagan Revolution, A FIRSTHAND ACCOUNT 81-83 (1991) (criticizing the Bowers decision as "either an imposition of very great cruelty or an exercise in hypocrisy inviting arbitrary and abusive applications of the criminal law"); LAURENCE H. TRIBE, AMERICAN CONSTITUTIONAL LAW 1422-35 (2d ed. 1988) (criticizing the Bowers decision as failing to acknowledge the underlying value of the right of privacy as protecting intimate human associations); Daniel O. Conkle, The Second Death of Substantive Due Process, 62 IND. L.J. 215, 235-36 (1986) (describing the Bowers decision as "deviant" and "perverse"); Janet E. Halley, Reasoning About Sodomy: Act and Identity in and After Bowers v. Hardwick, 79 VA. L. REv. 1721, 1770 (1993) (characterizing the Bowers decision as "the [judicial] exercise of homophobic power"); Lance Liebman, $A$ Tribute to Justice Byron R. White, 107 HARV. L. REv. 13, 19 (1993) (pointing to Bowers as Justice White's least convincing and worst opinion); Kendall Thomas, The Eclipse of Reason: A Rhetorical Reading of Bowers v. Hardwick, 79 VA. L. REV. 1805, 1806 (1993) (arguing that Bowers reflects a "homophobic ideology").

Indeed, Justice Powell, one of the five Justices in the Bowers majority, essentially changed his vote after stepping down from the Court. In remarks made at New York University, Powell said, "I think I probably made a mistake" in voting with the majority in Bowers. He stated that upon rereading the decision a few months after it was issued, "I thought the dissent had the better of the arguments." Linda Greenhouse, When Second Thoughts in Case Come Too Late, N.Y. TIMES, Nov. 5, 1990, at A14.

For an argument that the First Amendment provides a doctrinal route to reversing Bowers, see Cole \& Eskridge, supra note 103.

201 See supra notes 93-98 and accompanying text.

202 See supra note 13.

${ }^{203}$ See supra note 48.

${ }^{204}$ See, e.g., Ruben Castaneda, District Reexamines Sodomy Law, WASH. POST, Feb. 26, 1992, at BI (reporting that District of Columbia City Administrator Robert L. Mallet characterized the District's sodomy statute as one generally used only in nonconsensual situations and as "not a primary law enforcement concern"); Deb Price, There Ought Not to be a Law, Gannett News Service, July 9, 1993, available in LEXIS, News Library, Wires File (asserting that actual sodomy prosecutions are rare).

${ }^{205}$ See Kendall Thomas, Beyond the Privacy Principle, 92 CoLUM. L. REv. 1431, 1464 (1992) (noting that violence against gay men and lesbians is a "structural feature of life in American society"); Thomas, supra note 200, at 1832 (asserting that the Bowers decision rigidified sexual roles, setting homosexuals far apart from heterosexuals and 
This more complicated picture, and in particular the disjuncture between formal regulation and informal practice, offers a potential bridge between Freud and Foucault. As a formal matter, the law follows a Freudian pattern, and insists upon a sharp public/private line on matters of sexuality; in terms of actual enforcement, however, the lines are anything but sharp, and may reflect a more Foucauldian strategy of dispersed regulation. In practice, we allow a great deal of sexual expression to surface in public, but at the same time we insist on regulating its public manifestations, whether through the zoning of red-light districts or the closely watched regulation of otherwise nude dancers' apparel.

\section{Art and Obscenity: An Issue of Control}

While Freud and Foucault disagree about the mechanisms by which power operates with respect to sexuality, both identify sexuality as a central target of social control. Art critic Lynda Nead provides some insight into why we target sexuality in her study of "the female nude." She sees the female nude as "the border... between art and obscenity. ${ }^{206}$ Both art and obscenity take as a primary subject the naked female body, which in a patriarchal culture represents all that is threatening about the "other": excess, passion, the unknown. But while art and obscenity share this common subject, our culture insists on drawing the sharpest of distinctions between them. Under both American and British law, artistic expression and obscenity are mutually exclusive categories. ${ }^{207}$

Nead proposes that the distinction between art and obscenity derives from the perceived danger of losing control that the "other" presents. Art offers the illusion of mastery over its subject. Through the formal elements of artistic representation, the artist transforms the naked body into a "nude," represented, framed, and contained. Thus, Kenneth Clark, who wrote the classic study of "the nude," wrote that "[ $t]$ he nude remains the most complete example of the transmutation of matter into form." ${ }^{208}$ The artist, Clark

making them susceptible to vilification); Deb Price, $A$ Gay Rights Crusader Finds Success At Last, STAR TRIB., Oct. 13, 1993, at E4 (stating that sodomy laws are "indirectly used to tar gay people and deny them jobs"); see also supra note 97 and accompanying text.

${ }^{206}$ NEAD, supra note 91 , at 25.

${ }^{207}$ See id. at 90 (noting that "artistic merit" is a defense to prosecution under Great Britain's Obscene Publications Act of 1959); see also Miller v. California, 413 U.S. 15, 24 (1973) (defining obscenity as expression lacking any serious artistic merit). ${ }^{208}$ KENNETH ClaRk, THE NUDE: A STUDY IN IDEAL FORM 27 (1956). Not 
argued, "clothes" the naked body in artistic form, guided by the formal rules of artistic representation. ${ }^{209}$ As Nead points out: "[I]f art is defined as the conversion of matter into form, imagine how much greater the triumph for art if it is the female body that is thus transformed-pure nature transmuted, through the forms of art, into pure culture. ${ }^{n 210}$

By contrast, Nead argues, obscenity represents that which cannot be controlled. The term "obscene," she points out, "may be a modification of the Latin 'scena,' so meaning literally what is off, or to one side of the stage, beyond presentation." 211 Where artistic representation reflects the triumph of form over matter, obscenity is that which cannot be represented on stage, that which is beyond form.

If ... art is seen to represent the sublimation or transformation of sexual drives, then pornography conveys the sexual unmediated; it incites and moves the viewer to action. The pure aesthetic experience is posed as a consolidation of individual subjectivity; it can be seen in terms of the framing of the subject. In contrast, the experience of pornography is described as a kind of disturbance; it presents the possibility of an undoing of identity. ${ }^{212}$

Nead compares the line between art and obscenity to Immanuel Kant's distinction between the beautiful and the sublime. Kant wrote that " $[t]$ he Beautiful in nature is connected with the form of the object, which consists in having boundaries." 213 The sublime, by contrast, "is to be found in a formless object, so far as in it or by occasion of it boundlessness is represented, and yet its totality is also present to thought."214 Like the sublime, Nead suggests, the obscene represents the threat of limitlessness, of the absence of boundaries. 215

From this perspective, the law's attempt to regulate the public representation of sexuality may be understood as an attempt to limit the limitless, to assert the power to control that which risks being beyond control. Like the pasties and G-strings mandated by

coincidentally, Clark is best known for his BBC television series, Civilisation, which was shown throughout the United States on PBS. See NEAD, supra note 91, at 12.

${ }^{209}$ See generally CLARK, supra note 208, at 1-29.

${ }^{210} \mathrm{NEAD}$, supra note 91 , at 18.

211 Id. at 25.

212 Id. at 28.

$213 \mathrm{KANT}$, supra note 60 , at 101-02.

214 Id. at 102.

215 See NEAD, supra note 91 , at 29-30. 
Indiana's nude dancing law, the regulation of sexual expression insists on imposing a limit, any limit, no matter how tenuous or fleeting that limit may be, for the sake ultimately of the limit itself. Uncontrolled sexual expression presents the same threat that the naked female body presents; the legal regime, like the regime of artistic form, provides a way (for men) to assert mastery over this foreign subject.

But while Nead's dichotomy captures much of what makes obscenity dangerous, her view of the pornographic as "the sexual unmediated ${ }^{\text {216 }}$ fails to recognize the extent to which pornography (and at least in this culture, sexuality) is itself already dependent upon limits. While the obscene challenges and defies the limits that law imposes, at the same time it could not exist without those limits. Far from being "unmediated," pornography is a highly formalized genre, subject to and dependent upon an elaborate set of rules.

\section{E. Taboo and Transgression: The Erotic Limits of Law}

While Freud, Foucault, and Nead explain the regulation of sexuality as protecting civilization from the disruptions and dangers attendant to sex, it may also be understood as protecting sex from civilization. By maintaining an aura of mystery and imposing a set of taboos, the regulation of sexual expression contributes (in most instances unconsciously) to what makes sex sexy. As Elizabeth Cowie has suggested: "[S]exuality is never a mere biological fact; rather, it is also a social concept . . . . It is constructed by the social discourses of a community or society. Central to this construction is the opposition permitted/forbidden or proper/improper. ${ }^{217}$

Foucault saw this dynamic in all regulation of sexuality, be it legal, professional, medical, or social:

The medical examination, the psychiatric investigation, the pedagogical report, and family controls may have the over-all and apparent objective of saying no to all wayward or unproductive sexualities, but the fact is that they function as mechanisms with a double impetus: pleasure and power. The pleasure that comes of exercising a power that questions, monitors, watches, spies, searches out, palpates, brings to light; and on the other hand, the pleasure that kindles at having to evade this power, flee from it, fool it, or travesty it. The power that lets itself be invaded by the

${ }^{216}$ See supra text accompanying note 212.

${ }^{217}$ Elizabeth Cowie, Pormography and Fantasy: Psychoanalytic Perspectives, in SEx EXPOSED, supra note 14, at 132, 133. 
pleasure it is pursuing; and opposite it, power asserting itself in the pleasure of showing off, scandalizing, or resisting. ... These attractions, these evasions, these circular incitements have traced around bodies and sexes, not boundaries not to be crossed, but perpetual spirals of power and pleasure. ${ }^{218}$

In this account, sexuality is neither separate from nor prior to social control, but is a function of the very social control asserted over it. Like an adult game of "hide-and-seek," the regulation of sexuality creates much of the attraction and excitement that surrounds sexuality, and indeed constructs what we understand as "sexuality."

Much of pornography's appeal lies in approaching and transgressing the social taboos that we develop to regulate it. Simone de Beauvoir, describing the infamous pornographer Marquis de Sade's philosophy, stated "[n]o aphrodisiac is so potent as the defiance of Good." 219 As Ellen Willis has argued, "However loudly people proclaim that porn is as wholesome as granola, the essence of its appeal is that emotionally it remains taboo. ${ }^{220}$ Similarly, Mary McIntosh has maintained that because "an essential ingredient of pornography [is] the desire to shock, to cross the boundaries, to explore forbidden zones," pornography "represents a contradiction within bourgeois Christian morality, in that it exists only because it is condemned. Pornography and censoriousness are an inseparable couple." ${ }^{221}$ Thus, civilization and its rules are at least as necessary

${ }^{218}$ FoucAult, supra note 180 , at 45 ; see also Vance, supra note 71 , at 45 (describing titillation of Meese Commission hearings).

${ }^{219}$ Simone de BeauvoIr, Must We Bum Sade?, in ThE MarQuis de SAde: The 120 DAYS OF SODOM AND OTHER WRITINGS 28 (1966).

${ }^{220}$ ELLEN WILlis, Feminism, Moralism, and Pormography, in BEGINNING TO SEe THE LIGHT: PIECES OF A DECADE 219 (1981). She notes further that "pornography is the return of the repressed, of feelings and fantasies driven underground . . . Prurience-the state of mind I associate with pornography-implies a sense of sex as forbidden, secretive pleasure." Id. at 220-21.

${ }^{221}$ Mary McIntosh, Liberalism and the Contradictions of Sexual Politics, in SEX EXPOSED, supra note 14, at 155, 166. Lynne Segal makes a similar point:

What we do not find in pornography-hence its provocation-are the acceptable male emotions associated with the approved discourses on male sexuality. Sex restrained by love and marriage, sex which is 'protective,' 'respectable' and 'faithful,' reverses into its opposite: sex greedy for immediate, unlimited, self-centered gratification. But would we have the pornographic representation without the accompanying authoritative discourses of and on men and their sexuality? The mirroring themes of the acceptable and transgressive discourses on sexuality suggest a dialectical relation between the two.

Segal, supra note 69, at 68 (emphasis added); see also SUSAN GRIFFIN, PORNOGRAPHY AND SILENCE: CULTURE'S REVENGE AGAINST NATURE 15 (1981) (stating that "the pornographer is obsessed with the idea of transgression"); Joel Kovel, The Antidialectic 
for keeping pornography exciting as pornography's repression is necessary for keeping civilization civilized. ${ }^{222}$

Pornography's dependence on taboo is so strong that even where the law does not draw lines, pornographers themselves draw them. Thus, soft-core pornography, of the sort that appears in Playboy or Penthouse, obeys careful strictures that are not legally imposed at all. Most pictorials depict women only, either alone or in pairs. Where men enter the picture, their genitals are generally obscured; if a penis is displayed, it is never erect. And actual penetration is virtually never depicted. ${ }^{223}$

Hard-core pornography, by contrast, is full of erect penises and penetration. ${ }^{224}$ Even here, however, lines are carefully drawn. One line, ever present at least in theory, is that hard-core pornography may be deemed obscene, something not even theoretically possible with soft-core pornography. ${ }^{225}$ Moreover, hard-core pornography also places limits on the representation of men as sex objects: while sex between women and heterosexual sex are staples of hard-core pornography, sex between men is generally restricted to pornography distinctively identified as gay or bisexual.

At first, these strictures, largely self-imposed, seem paradoxical. Pornography presents itself as liberating, yet religiously heeds its own self-imposed limits. In part, these distinctions may be an attempt to target different markets of desire. But they also suggest

of Pomography, in MEN CONFRONT PORNOGRAPHY 153, 159 (Michael S. Kimmel ed., 1990) ("If there were no taboos to transgress, there would be no interest at all in pornography.")

${ }^{222}$ Studies suggest that the existence of restrictions on sexually explicit materials may make them more desirable. See Maurice Yaffe, Pornography: An Updated Review (1972-1977), in COMMITTEE ON FILM CENSORSHIP, supra note 73, at 235, 238; see also Howard L. Fromkin \& Timothy C. Brock, Erotic Materials: A Commodity Theory Analysis of the Enhanced Desirability That May Accompany Their Unavailability, $3 \mathrm{~J}$. APPLIED SOC. PSYCHOL. 219, 219 (1973) (reporting that "making erotic materials more difficult to obtain ... may increase interest in the materials"). This may explain the pornographic film industry's penchant for labeling their films " $\mathrm{X}$ " and "XXX," playing on the nonpornographic film industry's ratings system. Cf. 1 ATTORNEY GENERAL, supra note 55, at 279-80 (discussing the Motion Picture Association of America rating system).

${ }^{223}$ See ANNETTE KuHN, THE POWER OF THE IMAGE: Essays ON REPRESENTATION AND SEXUALITY 33 (1985) (noting that "[p]hotographs of erect penises, for example, are usually confined to hardcore and to gay male pornography, while representations of acts of heterosexual intercourse are also limited in availability").

${ }^{224}$ See id. at 33-34, 44-46.

${ }^{225}$ Soft-core pornography is likely to fail one or both of the obscenity requirements that the material be "patently offensive" and lack any significant artistic or social value. See supra text accompanying note 45. 
that pornographers intuit that their product's attraction might be lost if the lines were erased, and sex was actually "liberated." As Annette Kuhn explains: "In order to maintain its attraction, porn demands strictures, controls, censorship. Exposed to the light of day, it risks a loss of power. Pornography invites policing. ${ }^{226}$

Pornography's self-imposed lines also serve another function: they make it safe to indulge in sexual fantasies. By allowing individuals to choose precisely what type of fetish or practice they will view or read about, pornography gives the reader the freedom to lose himself without fear that he will really lose himself. ${ }^{227}$ The capacity to break free of one's inhibitions is part of what makes sex both exciting and dangerous. But just as children play more freely where there are some outside rules to guide them, adults may feel more free to lose themselves if they are assured of a limit. ${ }^{228}$ Thus, pornography's self-imposed limits paradoxically provide the illusion of danger and a promise of safety: you won't be too surprised.

The laws we impose on sexual expression play a similar paradoxical role. Indiana's legally-mandated pasties and G-strings, for example, may make nude dancing more appealing by representing a taboo to be challenged, and at the same time may give the viewer a sense of security: the law assures him that there are limits to the play in which he is engaging. Similarly, obscenity prohibitions simultaneously reinforce the taboo character of sexual speech and assure readers and viewers that the bulk of pornography is socially acceptable. By constitutional definition, obscenity laws may proscribe only those sexually explicit materials which are patently

${ }^{226}$ KuHN, supra note 223, at 23.

${ }^{227}$ Indeed, because it is generally consumed on a solitary basis, the reader or viewer of pornography retains ultimate control. He or she may close the book, stop the video, or hang up the phone at any point. The only "other" in pornography is the represented "other," far less threatening than a partner who might assert his or her own independent will, and take one further than one dares to go.

${ }^{228}$ According to Susan Keller, practitioners of ritual sadomasochism expressly rely on such lines: once it is established that certain lines will not be crossed, or that the masochistic partner has the power to call a halt at any point, the couple is free to play with fears and desires about dominance and submission that they would not otherwise be willing to indulge. See Keller, supra note 58, at 2218-19. As Keller has noted, in "ritual [sadomasochism], the erotic quality may be enhanced by the fact that the violence is contained and controlled by the parties, allowing them to be aware of the ritual as well as the immediate experience." Id. at 2219; see id. at 2217-22 (describing various levels of sadomasochistic sex); see also STEVEN SEIDMAN, EMBATTLED EROS: SEXUAL POLITICS AND ETHICS IN CONTEMPORARY AMERICA 115-22 (1992) (discussing lesbian sadomasochism). 
offensive, appeal to a "shameful or morbid interest in sex," and have no literary, artistic, or social value. ${ }^{229}$ Because this prohibition is so narrow, it serves in practice not so much to purge the community of explicit sexually arousing speech as to validate everything that remains as nonoffensive, "normal," or socially valuable. In this way, obscenity doctrine collectively assures the community that the pornography it consumes at such a high rate is acceptable.

If sexual speech regulation were limited to obscenity laws, however, the very legitimacy of nonobscene sexual expression might well deprive the bulk of pornography of its power. The regulation of "offensive" sexual speech allows nonobscene sexual expression to share in the attraction of the forbidden. It ensures that where sexual expression is publicly communicated, it is kept in the dark shadows of the public sphere-in the red-light districts of town, the cordoned-off sections of video stores, and the adults-only bars and movie theaters. The economic success of the pornography industry attests to society's demand for its products, but consumption is, for the most part, kept under the table. ${ }^{230}$ In addition to maintaining pornography's desirability as forbidden fruit, the zoning of sexual expression supports a strategy of plausible deniability for a society that feels guilty about the pornography it consumes. By keeping pornography off Main Street but not suppressing it altogether, we can have our cake while denying that we are hungry. ${ }^{231}$

At the same time, the lines drawn by pornography's social and self-regulation serve an ideological function. Kuhn has suggested that pornography's taboos underscore the centrality of its male

${ }^{229}$ See supra text accompanying notes 5-9.

${ }^{230}$ Pornography has been estimated as a $\$ 7-8$ billion per year industry. See Maureen Dowd, Yes, But Can She Make Them Swoon?, N.Y. TIMES, May 26, 1991, at E3 (estimating annual revenues at $\$ 7$ billion per year); Joseph L. Galloway \& Jeannye Thornton, Crackdown on Pornography-A No-Win Battle, U.S. NEWS \& WORLD REP., June 4,1984 , at 84,84 (estimating annual revenues at $\$ 8$ billion per year).

231 Elizabeth Cowie has argued that all regulation of sexual desire shares this paradoxical character:

It is a paradox that while sexual relations are pre-eminently the object of social control in human societies sexual desire is often taken to be something beyond social organization or rational control. The realm of the sexual is seen as par excellence the realm of the irrational, the anarchic-the realm of the senses. However, the opposition control/beyond control arises only once "control" is imposed .... The "beyond control" is then desire, including or especially sexual desire . ... Desire here is most truly itself when it is most "other" to social norms, when it transgresses the limits and exceeds the "proper."

Cowie, supra note 217, at 134 . 
heterosexual perspective:

[I]t appears hard to fathom why it is that both the sexual subjectivity which sets itself up as the cultural norm (masculinity) and the sexual practice we are all meant to strive for (heterosexuality) are both in certain respects unrepresentable. Photographs of erect penises, for example, are usually confined to hardcore and to gay male pornography, while representations of acts of heterosexual intercourse are also limited in availability. Such censorships, however, far from marginalising certain sexual practices, precisely construct them as the really important ones. ${ }^{232}$

If the pornographic representation of women constitutes a mechanism for men to assert control over women through objectification, we might well expect the rules to bar "equal" pornographic treatment of men, which is indeed relegated to "hard-core" gay or bisexual pornography. Lynne Segal has argued that the absence of the penis in soft-core pornography may reflect a concern that the metaphorical power of the phallus would be deflated by literal images of penises. ${ }^{233}$ The pornographic presentation of women provides the illusion that female sexuality-so threatening to men-can be "captured" by the camera; the relative absence of the penis correlatively implies that male sexuality remains beyond control. Still another possible explanation stems from men's fear of homoerotic desire; the consumer might find himself excited by the display of erect penises, which in turn might lead him to question his heterosexuality. Thus, pornography's lines not only maintain the allure of sexual expression, but underscore its ideology of heterosexual normativity and male dominance.

Conservatives view the threat posed by erasure of the lines of sexual repression and regulation as the loss of moral values. But at least as significant a threat may be the loss of sexual expression's particular appeal. Duncan Kennedy has argued that what makes a particular style of dress sexy is its deviation from the norm of the setting in which it is worn..$^{234}$ An outfit that might not be particularly sexy in the bedroom or on the beach may become sexy if worn in a less sexually-charged setting, such as a school, office, or

${ }^{232}$ KUHN, supra note 223, at 33-34.

233 See SEGAL, supra note 52, at 87-88; see also Jacques Lacan, The Meaning of the Phallus, in Feminine SeXuality 74, 82 (Juliet Mitchell \& Jacqueline Rose eds. \& Jacqueline Rose trans., 1982) (proposing that the "phallus can only play its role as veiled").

244 See Kennedy, supra note 69, at $1344-48$. 
supermarket. By alluding to the more sexually charged setting, sexy dress invites the imagination of the viewer into that setting. ${ }^{235}$ Sexy dress invites the public viewer to imagine a private encounter.

If everybody dressed sexy, Kennedy argues, the norm would simply change, and the dress would no longer be sexy. Normalization "deprives any particular sexy dress practice of its sexiness." 236 If dress that signifies "private" comes to signify "public," an essential element of its erotic appeal will be lost. The pasties and G-strings-and indeed public nudity laws generally-thus protect the sexiness of nudity, by mandating that nudity not be normalized. The lines we draw, it seems, are as important to sex as they are to civilization.

As we have seen, the most fundamental line of all in the regulation of sexual expression is the public/private distinction. Pornography would be virtually inconceivable without such a line to transgress: by representing sex for the consumption of others, pornography makes the private public. Its defining tropes are exhibitionism (from the standpoint of the pornographic model) and voyeurism (from the standpoint of the consumer), both of which make no sense unless there is a line between public and private to transgress. Thus, it is the very regulation of pornography that makes pornography possible.

The paradoxical effects of the regulation of sexual expression suggest that those who urge pornography's regulation may be engaging in a self-defeating enterprise. While it is at best speculative that such regulation will in fact uphold morality or further equality, the respective goals of fundamentalists and feminists, it is virtually certain that such regulation will enhance pornography's appeal. Like the pasties and G-string, whatever lines society draws will themselves be fetishized, and will become the focal points of

${ }^{235}$ See id. at 1372 (asserting that the "sexy dresser invites the straight male audience to imagine being with her in the setting [to which] her dress alludes").

${ }^{236} \mathrm{Id}$. at 1349; see also id. at 1361 ("[T]he pleasures of sex are connected with the pleasures of ideological contest and of transgression. Changing the norm might deeroticize behavior that had the pleasures of defiance or deviance.").

This theory suggests that the nude dancers in Barnes would have lost if they had won. They argued that the nude dancing law caused them economic injury in that they received larger tips when they danced entirely naked than when they wore pasties and a G-string. See Barnes v. Glen Theatre, Inc., 501 U.S. 560, 563 (1991). But that may well have been true only because the law prohibiting nude dancing, which made entirely nude dancing more desirable. If Indiana's law had been struck down, fully nude dancing would have become normalized, and the dancers would have had to challenge some other legal line in order to receive higher tips. 
desire. The fact that pornographers create their own lines suggests that the would-be regulators are playing into the pornographers' hands.

At the same time, if regulation of sexual expression has as much to do with keeping sex sexy as with keeping civilization civilized, one might question why anyone should be concerned about regulation at all. Like the separation of church and state, perhaps the public/ private line serves valuable ends for both sides of the equation. This conclusion, however, is too simple. There are in fact many victims of the rules that govern public sexual expression. There are the few who are actually prosecuted; given the remarkable amount and variety of sexual expression that goes without prosecution, to be prosecuted for obscenity these days is akin to being struck by lightning. ${ }^{237}$ And there are the surely larger number who are chilled by such rules: some may go through life unable to express or discover their sexual identity because of society's taboos about sexual expression; others will go ahead and violate the taboos but suffer substantial guilt and self-recrimination in doing so.

But most troubling of all may be the sexuality that these regulations produce. As Foucault stated, "what is involved is the production of sexuality rather than the repression of sex." ${ }^{238}$ The sexuality produced by social regulation of sexual expression is itself pornographic; it is obsessed with taboo and transgression. Sexuality need not be so limited. It can also be the most profound expression of love, connection, and commitment that two human beings can share. But because our society has been so obsessed with controlling and regulating sexual expression, we have elevated the aspects of transgression and taboo above all others. Just as the attempt to censor an artist may increase interest in the artist's work for the wrong reasons, so the regulation of sexual expression increases interest in precisely those aspects of sex that we seek to control, and for the wrong reasons. The regulation of sexual expression thus

${ }^{237}$ The Meese Commission reported that "[a]s a purely empirical matter, ... determinations of obscenity for even the most explicit and offensive of [sexually explicit] magazines seem aberrational, and by and large most of these magazines circulate widely throughout the country without significant legal attack." 1 ATTORNEY GENERAL, supra note 55, at 281. The inherent arbitrariness of such enforcement raises substantial concerns about fairness. Cf. Furman v. Georgia, 408 U.S. 238 (1972) (striking down the death penalty because its arbitrary application rendered it cruel and unusual punishment).

${ }^{238}$ FoUCAULT, supra note 180 , at 114. 
imposes a cost not only on our constitutional doctrine, but on the very meaning of sexuality. ${ }^{239}$

The notion that we have created a pornographic sexuality through the rules we have laid down is counterintuitive. Precisely because our social norms condemn pornography, we are likely to resist the suggestion that our conception of sexuality is itself inextricably tied to pornography and its regulation. We regulate pornography because we reject it as a "proper" form of sexual expression. The message that Americans enjoy relatively stable, monogamous, and routine sex lives-the interpretation that the news media initially gleaned from a recent survey of sex in America-is much easier to accept. ${ }^{240}$

But one need only open one's eyes to see the extent to which a pornographic conception of sex, obsessed with the erotics of transgressing taboos, dominates our culture. Pornographic magazines and videos do a thriving business. Even in more mainstream culture, sexual taboos and their transgression sell everything from movies to magazines to records to clothes to television shows to perfume. We are obsessed with those who dare to approach, play with, and transgress the rules: Calvin Klein advertisements, Madonna videos, Prince songs, NYPD Blue, Cosmopolitan advice columns on adding spice to your sexual life, and daytime talk shows featuring those who have broken the rules and lived to tell their story on national television.

- The rules we impose on the expression of sexuality-whether legal, cultural, or religious-ultimately fuel these obsessions and channel our conception of sexuality into the very transgressive

${ }^{239}$ I do not mean to suggest that a prior notion of sexuality-pure, unalienating, and loving-has been corrupted by social regulation. Rather, I simply note that other conceptions of sexuality are possible, and that the regulatory impulse produces a particular and particularly pornographic conception.

${ }^{240}$ See LAUMANN ET AL., supra note 68, at 375, 546-47; Philip Elmer-Dewitt, Now for the Truth About Americans and Sex, TIME, Oct. 17, 1994, at 64 (reporting that the survey suggests that "the sex lives of most Americans are about as exciting as a peanut-butter-and-jelly sandwich"); Joannie M. Schrof \& Betsy Wagner, Sex in America, U.S. NEWS \& WORLD REP., Oct. 17, 1994, at 74, 76 (noting that the sex survey shows that "Americans are doing less with each other sexually than the images gleaned from popular culture would imply-and when they do have sex, it's pretty conventional"). Because the survey was based on face-to-face interviews, it is quite possible that the results were skewed by the subjects' reluctance to be candid about intimate questions posed by strangers, even under a guarantee of confidentiality. See LAUMANN ET AL., supra, at 55-60. Indeed, $21 \%$ of the survey interviews were conducted in the presence of a spouse, children, or other person raising further questions about candor. See id. at 568 . 
ideology that, at least on the surface, we seek to suppress. ${ }^{241} \mathrm{We}$ are caught, ultimately, in a cycle of prohibition and transgression. This cycle simultaneously offers the illusion of control by enforcing a set of lines, and the illusion of danger, as the forbidden is eroticized. But the cycle is a limiting one, as our imagination is imprisoned within the bounds of two contrary illusions, thereby avoiding the truly dangerous but also truly liberating possibilities of sexual communication with another.

The costs imposed by the paradoxical games we play in regulating sexual expression are most sharply reflected in the redlight district. The red-light district is a geographical marker of compromise that we have reached in the regulation of public sexual expression. Neither public nor private, it represents the margin of our sexual experience, the place to which we relegate "private" sexual expression in "public." The red-light district reveals both the impossibility of maintaining a sharp public/private line and the impoverished vision of sexuality we have constructed through our regulation of it. Partially exposed, partially hidden, but very much regulated (both legally and socially), the red-light district reflects all of our culture's ambivalent feelings towards sexual expression. The "red light" at once conjures the inviting colored light of a brothel's back room and the simplest of social directives: "Stop!" But as we have seen, the image of prohibition adds to the attraction. What is illegal elsewhere is permitted here; in the red-light district, the lines between public and private not only may be but are necessarily blurred. Here, sex and its representations, the most private of goods, are sold and exchanged on the public market, but always "under wraps." Precisely because pornography fetishizes whatever line the law imposes, a sharp public/private line cannot be maintained. The red-light district is civilization's compromise with sex.

But is this the kind of compromise we really want? The red-light district, as the Court expressly recognized in Young $v$. American Mini Theatres, Inc. and Renton v. Playtime Theatre, Inc. is a dark and dismal place, populated by unsavory characters and redolent with "second-

${ }^{241}$ In some sense, of course, fascination with transgression is an inevitable byproduct of regulation of any sort and is not limited to regulation of sexual expression. But taboos around expression have a particularly strong effect in this regard; censorship of ideas seems to lead to stronger interest and curiosity in the suppressed than does prohibition of illegal conduct. Moreover, taboos have a freight in the sexual setting that they seem to bear nowhere else. 
ary effects." The image of sex reflected by this "boundary line" is cheap and tawdry; it has everything to do with the excitement of the forbidden and little to do with communication with another. Nor could we "solve" the problem by banning red-light districts; the boundary line would simply reappear somewhere else, with all of the same effects. If this is the limiting case of our regulation of sexuality, it suggests that the regulatory strategy is deeply misguided. The red-light district reveals what our attempts to assert mastery and control over sexuality produces: pornography itself.

\section{CONCLUSION}

I have argued that the regulation of sexual expression cannot be justified under traditional speech doctrines and indeed inverts two of the First Amendment's most fundamental principles: the maxim that the First Amendment's central purpose is to protect public dialogue from official censorship, and the "bedrock principle"242 that society may not censor expression merely because it finds it offensive, morally or otherwise. The regulation of sexual expression excludes sexual expression from public debate precisely because a majority claims to find its public expression morally offensive. That the Supreme Court has endorsed such an inversion of First Amendment values suggests that the Court considers the benefits served by policing the public/private line to outweigh First Amendment principle. Yet neither the Court nor commentators have devoted much attention to the effects that enforcing that line has on society or sexuality.

Although the public/private line is conventionally seen as essential to maintain the values of civilization, it plays an equally central role in the construction of sexuality. In large part, what makes sexual expression sexy in our culture is the potential for transgression, for abandonment of inhibitions, and for the play of fantasy. Social prohibitions ironically contribute to this conception of sexuality by constructing lines to transgress, inhibitions to abandon, and a "normal" reality against which fantasies may be played out. Pornographers play along with the lines society draws and even go further by drawing their own lines. Society regulates sexual expression because of its perceived dangers, yet without such regulation sexual expression might well lose some of its "dangerous" appeal.

${ }^{242}$ Texas v. Johnson, 491 U.S. 397, 414 (1989). 
Thus, while conventional accounts of sexual regulation portray the sex drive as an otherwise unrestrained libidinal instinct that must be contained, sublimated, and regulated to serve the interests of civilization, I have suggested that the sex drive is itself shaped by the regulatory lines we draw and precisely by the excitement that transgressing those taboos promises. The regulation of sexual expression reveals at bottom, not a struggle between social order and sexual anarchy, but a dynamic in which both law and sex are inextricably dependent on the drawing of lines. Paradoxically, then, sexual expression to some extent will always elude society's desperate attempts to regulate it, because sexual expression transforms whatever taboo is imposed into a fetish.

By our regulatory obsession we have constructed a very particular type of sexuality, one in which transgressing lines and violating taboos is central to sexual excitement. We should not (and most of us do not) assume that such a construction of sexuality is necessary or inevitable. But this construction of sexuality is so strongly determined in our culture-by the very regulations we impose-that it is difficult to conceive of sexuality in other than transgressive terms. This construction of sexuality limits the possibilities for alternative visions of sexuality, visions that are not delimited by the transgression of taboos. Both the traditional critics of pornography, who envision a sexuality characterized by love and devotion, and the feminist critics, who seek a sexuality predicated on equality between women and men, undermine their own causes by focusing on suppression as the means for achieving those ideals. They would do better not to seek to control sexual expression, but instead to participate in affirmative private and public exploration of alternative visions. In the end, not only the First Amendment, but sexuality itself, demand more speech, not less. More regulation and less speech will only ensure that we remain bound to a pornographic conception of sexuality. 
FROM THE EDITORS

On April 1, 1994, the University of Pennsylvania Law School presented the David L. Bazelon Conference in Science, Technology, and Law. The Conference honored Judge Bazelon and featured presentations by his former law clerks, Robert A. Burt, Alexander M. Capron, E. Donald Elliott, Steven P. Goldberg, Thomas W. Merrill, Martha Minow, and Peter L. Strauss. University of Pennsylvania faculty members Barry S. Cooperman, Michael A. Fitts, Frank I. Goodman, Heidi Hurd, A. Leo Levin, Susan P. Sturm, and Barbara Bennett Woodhouse provided commentary on the main presentations. The Law Review hopes that the following Conference excerpt reflects the uniformly high-caliber and provocative scholarship offered by the Bazelon Conference participants. 